\title{
Influence of Uranyl Speciation and Iron Oxides on Uranium Biogeochemical Redox Reactions
}

\author{
Brandy D. Stewart ${ }^{1 *}$, Richard T. Amos ${ }^{2}$, Peter S. Nico ${ }^{3}$, and Scott Fendorf ${ }^{1}$ \\ ${ }^{1}$ Environmental Earth System Science, Stanford University, Stanford, \\ CA 94305, USA \\ ${ }^{2}$ Department of Earth and Environmental Sciences, University of Waterloo, Waterloo, ON N2L \\ 3G1, Canada \\ ${ }^{3}$ Earth Sciences Division, Lawrence Berkeley National Laboratory, Berkeley, CA 94720, USA \\ *Corresponding author: \\ email: brandy.stewart@erc.montana.edu \\ phone: 406-994-7501
}




\section{Abstract}

Uranium is a pollutant of concern to both human and ecosystem health. Uranium's redox state often dictates its partitioning between the aqueous- and solid-phases, and thus controls its dissolved concentration and, coupled with groundwater flow, its migration within the environment. In anaerobic environments, the more oxidized and mobile form of uranium $\left(\mathrm{UO}_{2}{ }^{2+}\right.$ and associated species) may be reduced, directly or indirectly, by microorganisms to U(IV) with subsequent precipitation of $\mathrm{UO}_{2}$. However, various factors within soils and sediments may limit biological reduction of $\mathrm{U}(\mathrm{VI})$, inclusive of alterations in $\mathrm{U}(\mathrm{VI})$ speciation and competitive electron acceptors. Here we elucidate the impact of $\mathrm{U}(\mathrm{VI})$ speciation on the extent and rate of reduction with specific emphasis on speciation changes induced by dissolved $\mathrm{Ca}$, and we examine the impact of Fe(III) (hydr)oxides (ferrihydrite, goethite and hematite) varying in free energies of formation on $U$ reduction. The amount of uranium removed from solution during 100 h of incubation with S. putrefaciens was $77 \%$ with no Ca or ferrihydrite present but only 24\% (with ferrihydrite) and 14\% (no ferrihydrite) were removed for systems with $0.8 \mathrm{mM} \mathrm{Ca}$. Imparting an important criterion on uranium reduction, goethite and hematite decrease the dissolved concentration of calcium through adsorption and thus tend to diminish the effect of calcium on uranium reduction. Dissimilatory reduction of $\mathrm{Fe}(\mathrm{III})$ and $\mathrm{U}(\mathrm{VI})$ can proceed through different enzyme pathways, even within a single organism, thus providing a potential second means by which Fe(III) bearing minerals may impact $\mathrm{U}(\mathrm{VI})$ reduction. We quantify rate coefficients for simultaneous dissimilatory reduction of Fe(III) and U(VI) in systems varying in $\mathrm{Ca}$ concentration ( 0 to $0.8 \mathrm{mM}$ ), and using a mathematical construct implemented with the reactive transport code MIN3P, we reveal the predominant influence of uranyl speciation, 
specifically the formation of uranyl-calcium-carbonato complexes, and ferrihydrite on the rate and extent of uranium reduction in complex geochemical systems. 


\section{Introduction}

A century of uranium-ore mining and processing have created an inventory of uranium and cocontaminants in the environment that threaten human and ecosystem health. Uranium's partitioning between the solid and aqueous phases, and thus potential for transport, in surface and subsurface environments is controlled in part by its oxidation state. In oxidized, carbonatebearing settings, uranium commonly exists as the uranyl ion $\left(\mathrm{UO}_{2}{ }^{2+}\right)$ associated with a variety of uranyl-carbonato complexes such as $\mathrm{UO}_{2}\left(\mathrm{CO}_{3}\right)_{2}{ }^{2-}$ and $\mathrm{UO}_{2}\left(\mathrm{CO}_{3}\right)_{3}{ }^{4-}$ ( Lovley, 1991; Clark et al., 1995; Brooks et al., 2003;), which, in the absence of Ca, account for $\sim 95 \%$ of U(VI) in solution in a typical groundwater (Abdelouas et al., 1998a) —a pH of $\sim 6.9$, temperature of $16^{\circ} \mathrm{C}$, and $\mathrm{HCO}_{3}{ }^{-}$and $\mathrm{U}(\mathrm{VI})$ concentrations of $1 \mathrm{mM}$ and $4 \mu \mathrm{M}$ respectively. Inclusion of $\mathrm{Ca}$, however, results in two ternary calcium-uranyl-carbonato species, $\mathrm{CaUO}_{2}\left(\mathrm{CO}_{3}\right)_{3}{ }^{2-}$ and $\mathrm{Ca}_{2} \mathrm{UO}_{2}\left(\mathrm{CO}_{3}\right)_{3}$, emerging as dominant aqueous species, often accounting for $>99 \%$ of U(VI) in solution (Bernhard et al., 1996, 2001; Kalmykov and Choppin, 2000; Kelly et al., 2003; Dong and Brooks, 2006).

In anaerobic environments, $\mathrm{U}(\mathrm{VI})$ is often reduced to $\mathrm{U}(\mathrm{IV})$ in the presence of dissimilatory metal-reducing bacteria (DMRB) ( Lovley, 1991; Gorby and Lovley, 1992; Liu et al., 2002) and sulfate reducing bacteria (SRB) (Ganesh et al., 1997; Payne et al., 2002) that couple the reduction of metals such as $\mathrm{U}(\mathrm{VI})$ with the oxidation of carbon or $\mathrm{H}_{2}$; in the specific case of $\mathrm{U}(\mathrm{VI})$ reduction, the result subsequent to reduction is precipitation of sparingly soluble $\mathrm{UO}_{2}$ ( Lovley, 1991; Brooks et al., 1999; Fredrickson et al., 2000). In fact, microbially mediated reductive immobilization of uranium has been studied as a potential form of stimulated natural attenuation in several contaminated sites (Anderson et al., 2003; Michalsen et al., 2006; Wu et 
al., 2006b). However, several factors including competing electron acceptors in the form of nitrate and Fe(III) (hydr)oxides (Abdelouas et al., 1998b; Wielinga et al., 2000; Wu et al., 2006a), for example, and the potential for re-oxidation of $\mathrm{UO}_{2}$ by a variety of oxidants including molecular oxygen and Fe(III) ( Wan et al., 2005; Moon et al., 2007; Wu et al., 2007), may limit reductive immobilization and thus diminish the long term effectiveness of this remediation strategy. Additionally, several studies have focused on describing kinetic behavior and quantifying rates of uranium reduction by DMRB and SRB; both Spear et al. (2000) and Lui et al. (2002) reproduced U(VI) reduction trends with first order models, and Luo et al. described concurrent U(VI) and sulfate reduction with a saturation kinetic model (2007). However, changes in uranyl speciation, particularly those driven by the presence of $\mathrm{Ca}$, can drastically impact microbial reduction of uranium (Brooks et al., 2003; Neiss et al., 2007; Stewart et al., 2007). Brooks et al. (2003), for example, observed a $40 \%$ decrease in U(VI) reduction by Shewanella putrefaciens over a $30 \mathrm{~h}$ period upon the addition of $0.45 \mathrm{mM} \mathrm{Ca}$, as compared to reduction without $\mathrm{Ca}$. Additionally, dissolved $\mathrm{Ca}$ and calcium-bearing minerals can decrease $\mathrm{U}(\mathrm{VI})$ adsorption to soils and sediments, increasing the propensity for migration in the subsurface (Fox et al., 2006; Meleshyn et al., 2009; Stewart et al., 2010).

The presence of Fe(III) imparts a variety of complicating constraints on uranium reduction, and consequently on its mobility under transport conditions. Firstly, uranyl (and associated species) can adsorb to the surface of $\mathrm{Fe}$ (hydr)oxide mineral phases (predominately in the absence of $\mathrm{Ca}$ ); reductive dissolution of Fe(hydr)oxides thus can subsequently release $\mathrm{U}(\mathrm{VI})$ into solution, increasing aqueous concentration. Additionally, owing to comparable (and overlapping) redox couples of $\mathrm{U}(\mathrm{VI} / \mathrm{IV})$ and $\mathrm{Fe}(\mathrm{III} / \mathrm{II})$, iron can act as an oxidant or reductant of uranium 
depending on specific geochemical conditions that often dictate uranyl speciation (Figure 1, (Ginder-Vogel et al., 2006)). Similarly Fe(III) can act as a competing terminal electron acceptor in microbial respiration, potentially decreasing both the rate and extent of uranium reduction. Wielinga et al. (2000) for example, observed a 52\% decrease in uranyl reduction by Shewanella alga, strain $\mathrm{BrY}$, in the presence of ferrihydrite, compared to only uranyl in solution, over a period of $10 \mathrm{~h}$, while, in contrast, neither goethite nor hematite impacted uranyl reduction. Dissimilatory U(VI) and Fe(III) reduction by DMRB may occur simultaneously due to overlapping redox couples and different forms of substrate (aqueous vs. solid), as well as distinct enzyme pathways. As summarized previously (DiChristina et al., 2005), Shewanella respiration on solid phase $\mathrm{Fe}(\mathrm{III})$, including $\mathrm{Fe}$ (hydr)oxides, likely proceeds via terminal reductases associated with the outer membrane of the cell; the terminal reductase(s) for $\mathrm{U}(\mathrm{VI})$ reduction appear to reside in the periplasm (for Gram-negative bacteria) and possibly on the outermembrane.

The intricate association between iron and uranium combined with the controlling influence of uranyl speciation convolutes our ability to quantitatively predict the fate and transport of $U$ in soils and sediments. Limiting our ability to predict $U$ reduction is the absence of rate information specifically describing the impacts of uranyl speciation, particularly those involving ternary complexes of $\mathrm{Ca}$, or soil/sediment matrix effects. The aim of this study is thus to provide a quantitative framework on bacterial reduction of $\mathrm{U}(\mathrm{VI})$ at varying concentrations of dissolved calcium and to determine the impact of Fe(III) (hydr)oxides, varying systematically in free energy of formation, on reduction rates. In addition to a kinetic analysis, we develop a quantitative biogeochemical model for $\mathrm{U}$ transformation using the reactive transport code 
MIN3P (Mayer et al., 2002), which is broadly applicable to geochemical problems involving kinetically controlled redox and mineral dissolution/precipitation reactions along with equilibrium hydrolysis, aqueous complexation, ion exchange, and surface complexation reactions. The results of this study provide an understanding of geochemical limitations on microbial uranium reduction imposed by $\mathrm{Ca}$ and modifications induced by $\mathrm{Fe}$ (hydr)oxides within the mineral matrix of soils and sediments, helping to predict the potential for migration in environmental settings.

\section{Materials and Methods}

\section{Cell Culturing and Harvesting}

Shewanella putrefaciens, strain CN32, a facultative, dissimilatory metal-reducing bacterium, was used to evaluate the effect of calcium on biological uranyl reduction in batch studies involving ferrihydrite-coated quartz sand. The culture was obtained from the American Type Culture Collection (ATCC catalogue number BAA-453), cultured aerobically in tryptic soy broth (TSB) until late log phase, and then frozen in $20 \%$ glycerol at $-80^{\circ} \mathrm{C}$ where it was stored until needed.

Shewanella putrefaciens was grown aerobically by placing $1 \mathrm{~mL}$ of frozen stock culture in 100 $\mathrm{mL}$ of TSB. The culture was placed on a shaker at room temperature for $12 \mathrm{~h}$ (late log phase) before it was transferred into the same medium and incubated while shaking for an additional 12 h. It was then centrifuged at $4500 \mathrm{rpm}$ for $12 \mathrm{~min}$, re-suspended in $100 \mathrm{~mL}$ of bicarbonate buffer, and centrifuged a second time. Finally, the culture was suspended in $100 \mathrm{~mL}$ of PIPES buffered artificial groundwater medium for 30 min until the start of the experiment. The artificial groundwater medium consisted of the following ingredients (in $\mathrm{mg} / \mathrm{L}$ ): $\mathrm{KHCO}_{3}, 380$; 
$\mathrm{KCl}, 5 ; \mathrm{MgSO}_{4}, 50 ; \mathrm{NaCl}, 30 ; \mathrm{NH}_{4} \mathrm{Cl}$ 0.95; $\mathrm{KH}_{2} \mathrm{PO}_{4}, 0.95$; and $1 \mathrm{~mL}$ Wolfe's mineral solution. The media was buffered with $10 \mathrm{mM}$ PIPES (1,4-piperazinediethanesulfonic acid) at $\mathrm{pH} 7.0$ and made anoxic by boiling and cooling under a stream of $\mathrm{O}_{2}$-free $\mathrm{N}_{2}$ gas. Further details are described in Stewart et al. (2007).

\section{Synthesis of Iron (hydr)oxide-coated Sands}

Ferrihydrite was prepared according to the method described by Brooks et al. (1996). A solution of ferric chloride was rapidly titrated with sodium hydroxide over a period of approximately $10 \mathrm{~min}$ until a $\mathrm{pH}$ of 7 was reached. Chloride and $\mathrm{Na}$ were then removed from the ferrihydrite with sequential rinses.

Goethite was prepared using a slightly modified version of Atkinson et al. (1967). Ferric nitrate was combined with concentrated sodium hydroxide in the absence of $\mathrm{CO}_{2}$. An effort was made to keep $\mathrm{CO}_{2}$ out of the product during initial synthesis but not during the dialysis purification stage; $\mathrm{CO}_{2}$ adsorbed during product synthesis can significantly impact the zero point of charge of the product (Vangeen et al., 1994). Sodium hydroxide was slowly pumped into the ferric nitrate solution over a period of several hours until a $\mathrm{pH}$ of 12 was reached during continuous stirring. The slurry was then placed in a $60^{\circ} \mathrm{C}$ oven for $24 \mathrm{~h}$, and finally salts (and, in particular, residual nitrate) were removed by dialysis for a period of approximately $10 \mathrm{~d}$.

Finally, hematite was prepared following the method described by Schwertmann and Cornell (2000) in which a concentrated ferric nitrate solution is added gradually over a period of $4 \mathrm{~h}$ to boiling, distilled water. The solution was stirred constantly. The product was then cooled 
overnight and purified by dialysis for approximately $7 \mathrm{~d}$ to remove excess salts (in particular nitrate). X-ray diffraction analysis was performed on all three Fe (hydr)oxides to ensure purity of product.

The iron (hydr)oxides were prepared individually and then used to coat quartz sand as reported previously (Brooks et al., 1996; Hansel et al., 2003). Briefly, the iron (hydr)oxide slurry was poured over the quartz sand and mixed thoroughly by hand. The mixture was then left to dry for $48 \mathrm{~h}$ before being washed with de-ionized water. Iron concentration on the sands was approximately $10 \mathrm{~g} / \mathrm{Kg}$ (1\% by weight).

\section{Uranium(VI) Reduction Reactions}

In order to investigate the effects of aqueous calcium concentration on uranium reduction, we assembled batch systems containing S. putrefaciens, Fe(III) (hydr)oxide coated sand, artificial groundwater medium, uranyl acetate, and varying concentrations of $\mathrm{CaCl}_{2}$, under anoxic conditions in a glovebag (Coy Laboratory Products) with a $\mathrm{N}_{2}(95 \%): \mathrm{H}_{2}(5 \%)$ atmosphere. Lactate was provided in the groundwater medium as a carbon source and electron donor at a concentration of $3 \mathrm{mM}$. All solutions were made anoxic by boiling and cooling under a stream of $\mathrm{N}_{2}$ gas. Each $125 \mathrm{~mL}$ serum vial contained $1.0 \mathrm{~g}$ of $\mathrm{Fe}$ (hydr)oxide-coated sand, $\approx 10^{7}$ cells of S. putrefaciens, and $105 \mathrm{~mL}$ of groundwater media. Anoxic stock solutions containing Uacetate, $\mathrm{CaCl}_{2}$, and $\mathrm{KHCO}_{3}$ were allowed to equilibrate overnight before being sterilely injected into the batch bottles. Each batch system began with $0.168 \mathrm{mM} \mathrm{U}$, added in the form of uranyl acetate, $\mathrm{UO}_{2}\left(\mathrm{C}_{2} \mathrm{H}_{3} \mathrm{O}_{2}\right)_{2}$, and a $\mathrm{Ca}^{2+}$ concentration of either $0 \mathrm{mM}, 0.4 \mathrm{mM}, 0.6 \mathrm{mM}$, or $0.8 \mathrm{mM}$ (added as $\mathrm{CaCl}_{2}$ ). The batch systems were assembled in a glovebag and then shaken at room 
temperature outside the glovebag between samplings; bottles were brought into the glovebag during sampling. A separate experiment was run for each of the three Fe (hydr)oxides (goethite, ferrihydrite, and hematite) as well as an experiment with no iron (no-Fe control). A replicate set of ferrihydrite experiments were conducted for $100 \mathrm{~h}$ in order to measure solution and solid associated Fe(II) for input to the model. All of the aforementioned biotic systems were conducted in triplicate and error values were calculated as standard deviation of the three measurements divided by the square root of the number of measurements. Abiotic controls for each of the iron (hydr)oxides, and one without iron, were conducted in duplicate. The $\mathrm{pH}$ of all experimental systems was 7.0 for the duration of the study.

\section{Aqueous Analyses}

Aqueous samples were withdrawn using sterile syringes and filtered through $0.2 \mu \mathrm{m}$ membranes inside a glovebag at hourly intervals for the first $8 \mathrm{~h}$ of the experiment. Subsequent samples were collected approximately every 12 to $24 \mathrm{~h}$ for the next $7 \mathrm{~d}$ (with the exception of the ferrihydrite systems used for model input that were sampled for $4 \mathrm{~d}$ ). A final sample was collected on day 22. All samples were analyzed by inductively coupled plasma-optical emission spectrophotometry (TJA/IRIS Advantage) to determine the concentration of total uranium, iron, and calcium in solution. The ferrozine method (Stookey, 1970) was used to measure Fe(II). In systems containing ferrihydrite that were used for model input it was necessary to determine the total amount of $\mathrm{Fe}(\mathrm{II})$ produced. Ferrozine was also used to extract $\mathrm{Fe}(\mathrm{II})$ adsorbed to the surface of the solid as described previously (Ginder-Vogel et al., 2006). Following aqueous sampling, groundwater media from each system was decanted and ferrrihydrite-coated sand from each bottle was transferred to a small vial. Five-mL of ferrozine reagent were then added to each $1 \mathrm{~g}$ 
of ferrihydrite-coated sand and allowed to equilibrate for $20 \mathrm{~s}$, and $2 \mathrm{~mL}$ of ferrozine solution were then removed for analysis, allowing for quantification of $\mathrm{Fe}(\mathrm{II})$ both in solution and adsorbed to the surface of ferrihydrite.

\section{Model Development}

\section{Conceptual Model}

The primary reaction of interest in the system described here is the reduction of aqueous $\mathrm{U}(\mathrm{VI})_{(\mathrm{aq})}$ to $\mathrm{UO}_{2(\mathrm{~s})}$, given by:

$\mathrm{UO}_{2}^{2+}+\mathrm{H}_{2(a q)} \rightarrow \mathrm{UO}_{2(s)}+2 \mathrm{H}^{+}$

coupled to the oxidation of lactate,

$\mathrm{C}_{3} \mathrm{H}_{5} \mathrm{O}_{3}^{-}+2 \mathrm{H}_{2} \mathrm{O} \rightarrow \mathrm{C}_{2} \mathrm{H}_{3} \mathrm{O}_{2}^{-}+\mathrm{HCO}_{3}^{-}+\mathrm{H}^{+}+2 \mathrm{H}_{2(a q)}$.

In these simulations, we use the intermediate species $\mathrm{H}_{2(\mathrm{aq})}$ to represent electron equivalents as a means of computationally, but not mechanistically, decoupling the oxidation and reduction reactions.

In carbonate-bearing solutions the speciation of the uranyl ion is dependent on the concentration of $\mathrm{Ca}^{2+}$ in solution, with the following equilibrium reactions pertaining:

$$
\begin{array}{ll}
\left(\mathrm{UO}_{2}\right)_{2} \mathrm{CO}_{3}(\mathrm{OH})_{3}^{-}+4 \mathrm{H}^{+} \rightarrow 2 \mathrm{UO}_{2}{ }^{2+}+\mathrm{HCO}_{3}^{-}+3 \mathrm{H}_{2} \mathrm{O} & \mathrm{K}=10^{-11.19} \\
\mathrm{UO}_{2}\left(\mathrm{CO}_{3}\right)_{3}^{4-}+3 \mathrm{H}^{+} \rightarrow \mathrm{UO}_{2}{ }^{2+}+3 \mathrm{HCO}_{3}^{-} & \mathrm{K}=10^{-9.1470} \\
\mathrm{UO}_{2}\left(\mathrm{CO}_{3}\right)_{2}^{2-}+2 \mathrm{H}^{+} \rightarrow \mathrm{UO}_{2}{ }^{2+}+2 \mathrm{HCO}_{3}^{-} & \mathrm{K}=10^{-4.048} \\
\mathrm{UO}_{2} \mathrm{CO}_{3(a q)}+\mathrm{H}^{+} \rightarrow \mathrm{UO}_{2}{ }^{2+}+\mathrm{HCO}_{3}^{-} & \mathrm{K}=10^{-0.389} \\
\mathrm{Ca}_{2} \mathrm{UO}_{2}\left(\mathrm{CO}_{3}\right)_{3(a q)}+3 \mathrm{H}^{+} \rightarrow \mathrm{UO}_{2}{ }^{2+}+2 \mathrm{Ca}^{2+}+3 \mathrm{HCO}_{3}^{-} & \mathrm{K}=10^{-0.432}
\end{array}
$$


$\mathrm{CaUO}_{2}\left(\mathrm{CO}_{3}\right)_{3}^{2-}+3 \mathrm{H}^{+} \rightarrow \mathrm{UO}_{2}^{2+}+\mathrm{Ca}^{2+}+3 \mathrm{HCO}_{3}^{-} \quad \mathrm{K}=10^{-5.587}$

where uranyl-carbonato species are the dominant species in the absence of $\mathrm{Ca}$; in its presence, calcium-uranyl-carbonato species become the dominant species. Equilibrium constants for reactions 3-6 are from Guillaumont et al. (2003) and constants for reactions 7 and 8 are provided by Dong and Brooks (2006). For completeness, several other uranyl-carbonato and uranylhydroxide species are included in the simulation; however, these species have only minor affects on the aqueous speciation of the system. In these simulations we have assumed equilibrium conditions governed by the above set of equations.

The rate of $\mathrm{U}(\mathrm{VI})$ reduction (Equation 9) is dependent on the speciation of the uranyl ion, where the rate of reduction in solutions dominated by uranyl-carbonato species is much faster than in solutions dominated by calcium-uranyl-carbonato species (Brooks et al., 2003; Stewart et al., 2007). This dependence is described by the rate expression;

$R_{1}=k_{1} \sum\left\{U(V I)^{*}\right\}^{x_{1}}\left(\frac{\left[H_{2(a q)}\right]}{K_{H_{2(a q)}}^{S}+\left[H_{2(a q)}\right]}\right)+k_{1 b} \sum\left\{U(V I)^{+}\right\}^{x_{1 b}}\left(\frac{\left[H_{2(a q)}\right]}{K_{H_{2(a q)}}^{S}+\left[H_{2(a q)}\right]}\right)$

where $k_{1}$ and $k_{1 b}$ are rate constants, the curly brackets represent species activity, $x_{1}$ and $x_{1 b}$ are the order of the rate with respect to $\left\{\mathrm{U}(\mathrm{VI})^{*}\right\}$ and $\left\{\mathrm{U}(\mathrm{VI})^{+}\right\}$, respectively, square brackets represent total component concentrations, $K^{S}$ is a half saturation constant, and terms $\mathrm{U}(\mathrm{VI})^{*}$ and $\mathrm{U}(\mathrm{VI})^{+}$ identify the dominant $\mathrm{U}(\mathrm{VI})$ species in the absence and presence of calcium, respectively; specifically, $\sum\left\{U(V I)^{*}\right\}=\left\{\left(\mathrm{UO}_{2}\right)_{2} \mathrm{CO}_{3}(\mathrm{OH})_{3}^{-}\right\}+\left\{\mathrm{UO}_{2} \mathrm{CO}_{3(a q)}\right\}+\left\{\mathrm{UO}_{2}\left(\mathrm{CO}_{3}\right)_{2}^{2-}\right\}+\left\{\mathrm{UO}_{2}\left(\mathrm{CO}_{3}\right)_{3}^{4-}\right\}$ 
$\sum\left\{U(V I)^{+}\right\}=\left\{\mathrm{Ca}_{2} \mathrm{UO}_{2}\left(\mathrm{CO}_{3}\right)_{3(\text { aq })}\right\}+\left\{\mathrm{CaUO}_{2}\left(\mathrm{CO}_{3}\right)_{3}{ }^{2-}\right\}$

and in practice $k_{1}$ is set much higher than $k_{1 b} . k_{1}$ and $k_{1 b}$ are independent of $\mathrm{pH}$ and carbonate concentration as these effects are taken into account in the overall $\mathrm{U}(\mathrm{VI})$ reduction rate equation (Equation 9) through changes in concentration (and thus activity) of various U(VI) species (Equations 10 and 11).

The rate of lactate oxidation is given by;

$R_{2}=k_{2}\left(\frac{\left[\mathrm{C}_{3} \mathrm{H}_{5} \mathrm{O}_{3}^{-}\right]}{K_{\mathrm{C}_{3} \mathrm{H}_{5} \mathrm{O}^{-}}^{\mathrm{S}}+\left[\mathrm{C}_{3} \mathrm{H}_{5} \mathrm{O}_{3}^{-}\right]}\right)\left(\frac{K_{\mathrm{H}_{2(a q)}}^{I}}{K_{\mathrm{H}_{2(a q)}}^{I}+\left[H_{2(a q)}\right]}\right)$

where $k_{2}$ is the rate constant and specifies the maximum oxidation rate, and $K^{I}$ is an inhibition constant. The first term provides a rate-dependence on lactate, but in these experiments lactate is provided in large excess. The second term couples the rate of lactate oxidation to the uranium reduction through the component $\mathrm{H}_{2(\mathrm{aq})}$, which decreases the lactate oxidation rate with increasing $\mathrm{H}_{2(\mathrm{aq})}$ concentration. This simplified rate expression for lactate oxidation does not take into account microbial growth and decay parameters and assumes that microbial populations are established at the outset of the experiments and do not change significantly through the course of the experiment.

We observed that the inclusion of ferrihydrite to U(VI)/lactate systems decreased the reduction rate of U(VI) in some cases (Stewart et al., 2007) and hypothesized that Fe(III) was competing for lactate. The reductive dissolution of ferrihydrite is given by;

$$
\mathrm{Fe}(\mathrm{OH})_{3(s)}+0.5 \mathrm{H}_{2(a q)}+2 \mathrm{H}^{+} \rightarrow \mathrm{Fe}^{2+}+3 \mathrm{H}_{2} \mathrm{O}
$$

resulting in the production of $\mathrm{Fe}(\mathrm{II})$. The reductive dissolution of ferrihydrite is modeled 
as a kinetically controlled irreversible reaction:

$$
R_{13}=k_{13}\left(\frac{\left[H_{2(a q)}\right]}{K_{H_{2(a q)}}^{S}+\left[H_{2(a q)}\right]}\right)
$$

where the rate is primarily governed by the availability of the electron donor (expressed here as $\left.H_{2(a q)}\right)$, provided solid phase ferrihydrite is still present. Note that the rate expressions for U(VI) and $\mathrm{Fe}(\mathrm{III})$ reduction (equations 9 and 14) both contain equivalent electron donor terms, and thus are competitively linked to lactate oxidation.

An important aspect of the conceptual representation of the redox system described above is the competition between $\mathrm{U}(\mathrm{VI})$ and $\mathrm{Fe}(\mathrm{III})$ reduction. This is represented using an electron donor, symbolized here as $\mathrm{H}_{2(\mathrm{aq})}$, that represents any common donor (lactate, acetate, etc...) used in $\mathrm{U}(\mathrm{VI})$ and $\mathrm{Fe}(\mathrm{III})$ respiration. For the present case using lactate, the total rate of lactate oxidation is controlled by the rate constant $k_{2}$, effectively setting the rate of $\mathrm{H}_{2 \text { (aq) }}$ production, and the competition between the two reduction reactions involving U(VI) and Fe(III) is based on the relative magnitude of the respective rate constants, $k_{1}, k_{1 b}$, and $k_{13}$, with the total rate of these reactions dependent on the availability of $\mathrm{H}_{2(\mathrm{aq})}$ (electron equivalents) supplied by the lactate oxidation reaction.

In the simulations, adsorption of U(VI) to ferrihydrite surfaces is accounted for by using the initial aqueous concentrations after equilibration with ferrihydrite. Adsorption of Fe(II) is not considered in the model as experimental results are presented as the sum of both aqueous and adsorbed concentrations. Finally, Ca adsorption was minimal and thus not necessary for inclusion in the simulations. 
The conceptual framework presented in this model has some common features with both the Liu et al. (2002) and Luo et al. (2007) models. The first-order Liu et al. (2002) model also assumes a constant microbial population and describes $\mathrm{U}(\mathrm{VI})$ reduction with a first-order rate law. The Luo et al. (2007) model incorporates saturation and inhibition terms (arising from nitrate reduction); however, their model accounts for microbial growth and decay which this model does not. Neither of these models, however, captures the effect of U(VI) speciation on reduction rates.

\section{Model Parameters}

In total, two sets of simulations were run to represent the four no-ferrihydrite experiments and the four with-ferrihydrite experiments. Each set consisted of varying $\mathrm{Ca}^{2+}$ concentrations at 0.0 , $0.4,0.6$ and $0.8 \mathrm{mM}$ in the form of $\mathrm{CaCl}_{2}$. The simulations included 9 components: $\mathrm{H}^{+}, \mathrm{UO}_{2}{ }^{2+}$, $\mathrm{HCO}_{3}{ }^{-}, \mathrm{Ca}^{2+}$, lactate, acetate, $\mathrm{H}_{2(\mathrm{aq})}, \mathrm{Fe}^{2+}$, and $\mathrm{Fe}^{3+} ; 32$ aqueous species were included in the model to accurately determine mineral solubilities. Equilibrium constants for speciation reactions are from the WATEQ4F (Ball and Nordstrom, 1991) and MINTEQA2 (Allison et al., 1991) databases, and are updated where possible to be consistent with the Visual MINTEQ database. Initial solution chemistry was set to represent that of the batch experiments as is described above. In order to simulate the buffering capacity of the batch experiments, the simulations included an artificial buffering reaction to maintain the $\mathrm{pH}$ at a value of 7.0.

The simulations were run with a no-flow, arbitrary volume of water with effectively $100 \%$ porosity to represent the batch experiments. The simulations with ferrihydrite included a volume 
fraction of $4.14 \times 10^{-5} \mathrm{~m}^{3}$ ferrihydrite $/ \mathrm{m}^{3}$ to represent the ratio of ferrihydrite to solution in each batch experiment.

The rate expressions presented above leave 7 adjustable parameters for the non-ferrihydrite simulations and 8 for the with-ferrihydrite simulations, including 4 half-saturation/inhibition constants and 4 rate constants. The lactate half-saturation constant is unimportant, as lactate is assumed to be in excess in both the experiments and simulations. The $\mathrm{H}_{2(\mathrm{aq})}$ half-saturation (Equations 9 and 14) and inhibition constants (Equation 12) are used to couple the oxidation and reduction reactions and are both set at $1 \times 10^{-8} \mathrm{~mol} \mathrm{~L}^{-1}$. This relatively low value ensures that the rates of the reactions remain closely coupled; however, the model results are not sensitive to this value.

Of more importance to the simulation results are the rate constants, particularly, $k_{1}, k_{1 b}, k_{2}$, and $k_{13}$. In order to constrain the four key rate constants, these parameters were not adjusted individually for each of the eight simulations, but were kept constant for all simulations. Briefly, $k_{1}$ was calibrated to measured aqueous uranyl concentrations in the no-calcium/no-ferrihydrite simulations; subsequently, $k_{1 b}$ was calibrated in the $0.8 \mathrm{mM}$ calcium/no-ferrihydrite simulations; $k_{13}$ was calibrated to reproduce measured total ferrous iron concentration (adsorbed + aqueous) for the with-ferrihydrite simulations. The maximum rate of lactate oxidation, $k_{2}$, was determined for the with-ferrihydrite simulations as experimental results have shown that the total amount of lactate oxidation in $\mathrm{U}(\mathrm{VI})$ plus Fe(III) systems exceeds that of U(VI)-only systems (Revill, personal commun.). All rate parameters were determined by visual fit to the experimental data. 


\section{Results}

\section{Uranium(VI) Speciation}

Formation of the ternary $\mathrm{Ca}_{2} \mathrm{UO}_{2}\left(\mathrm{CO}_{3}\right)_{3}$ complex progressively increases, becoming the dominant uranyl species, over a $\mathrm{Ca}$ concentration range of 0 to $1 \mathrm{mM}$. At a calcium concentration of $0.2 \mathrm{mM}, 43 \%$ of uranium in solution is associated with one of the uranylcarbonato complexes at $\mathrm{pH} 7$ with $\left[\mathrm{CO}_{3}\right]_{\mathrm{T}}=3.8 \mathrm{mM}$ and $[\mathrm{U}(\mathrm{VI})]=0.168 \mathrm{mM}$ (Figure 2)uranyl-calcium-carbonato complexes account for the remaining $57 \%$ of the U(VI) species under these conditions. An increase in Ca concentration to $0.8 \mathrm{mM}$ results in $95 \%$ of the uranyl residing within the uranyl-calcium-carbonato complexes. The chemical speciation modeling program Visual MINTEQ was used to calculate these values.

This shift in speciation from a system dominated by uranyl-carbonato to one dominated by uranyl-calcium-carbonato complexes correlates with the observed decrease in $\mathrm{U}(\mathrm{VI})$ reduction by S. putrefaciens (Figure 3). This is reflected in the biogeochemical model by $\mathrm{k}_{1}$ and $\mathrm{k}_{1 \mathrm{~b}}$ having more than an order of magnitude difference in value: $\mathrm{k}_{1}=7.5 \times 10^{-6} \mathrm{~s}^{-1}, \mathrm{k}_{1 \mathrm{~b}}=3.1 \times 10^{-7} \mathrm{~s}^{-1}$ (ie $\left.\mathrm{k}_{1}>>\mathrm{k}_{1 \mathrm{~b}}\right)$. Reduction of the various uranyl species, when coupled with lactate oxidation, results in appreciable shifts in apparent energy yield but does not systematically decrease with the ternary Ca complexes (Table 1).

\section{Uranium(VI) Reduction}

Reduction of U(VI) by S. putrefaciens transpires at all Ca concentrations and with all 3 types of ferric (hydr)oxides investigated; however, both the rate and the extent of U(VI) reduction are dependent on $\mathrm{Ca}$ concentration - with an inverse relation between reduction rate and $\mathrm{Ca}$ concentration (Figure 3). With ferrihydrite, $\mathrm{U}_{(\mathrm{aq})}$ is reduced to $24 \%$ of its original concentration 
of $0.168 \mathrm{mM}$ after $528 \mathrm{~h}$ when no $\mathrm{Ca}$ is present in solution. In contrast, addition of $\mathrm{Ca}$ (initial concentrations of $0.4,0.6$, and $0.8 \mathrm{mM}$ ) results in a $50 \%$ reduction in $\mathrm{U}_{(\mathrm{aq})}$ after $528 \mathrm{~h}$. In the case of goethite, $\mathrm{U}_{(\mathrm{aq})}$ is reduced to $2 \%$ of starting concentration after $528 \mathrm{~h}$ with no Ca, while with $\mathrm{Ca}$, reduction is diminished and thus 20 to $35 \%$ of the initial $\mathrm{U}(0.168 \mathrm{mM})$ remains in solution after $528 \mathrm{~h}$. With hematite, reduction ranges from $100 \%$ (no Ca) to $80 \%$ depending on the $\mathrm{Ca}$ concentration (Figure 3 ). The addition of $\mathrm{Ca}$ to the no-Fe control system has the most dramatic affect on $\mathrm{U}(\mathrm{VI})$ reduction. After $528 \mathrm{~h}$ of reaction, the extent of $\mathrm{U}$ reduction decreases from $90 \%$ to $55 \%$ of the initial concentration with the addition of $\mathrm{Ca}-$ consistent with the findings of Brooks et al.(2003) .

\section{Iron(III) Reduction}

The concentration of $\mathrm{Fe}$ in the aqueous phase increased during the reaction period for ferrihydrite at all $\mathrm{Ca}$ concentrations (Figure 4), while the concentration of $\mathrm{U}$ in the aqueous phase decreased. The concentration of Fe generated after $528 \mathrm{~h}$ ranges from $0.11 \mathrm{mM}$ in the absence of $\mathrm{Ca}$, a concentration and rate comparable to that reported previously (Wielinga et al., 2000), to 0.29 $\mathrm{mM}$ in the presence of $0.8 \mathrm{mM} \mathrm{Ca}$. Dissolved Ca appears to correlate with the concentration of Fe(II) produced, supporting the premise that $\mathrm{Ca}$ renders $\mathrm{U}(\mathrm{VI})$ less favorable as a terminal electron acceptor, thus making Fe(III) the dominant electron acceptor. In contrast to the ferrihydrite system, negligible amounts $\left(<0.2 \mu \mathrm{mol} \mathrm{L}^{-1}\right)$ of aqueous Fe are detected in goethite or hematite systems (and in the no-Fe controls) at any Ca concentration; minimal Fe reduction transpired (less than the re-adsorption capacity of Fe(II) on goethite or hematite). The differences observed among the $\mathrm{Fe}$ (hydr)oxides are consistent with the surface area and free 
energy yields, where $\mathrm{Fe}$ is, at least initially, more available for bioreduction when present as ferrihydrite than either goethite or hematite (Hansel et al., 2003, 2004).

In order to quantify the impact of Fe(III) on U(VI) reduction used for model input, the concentration of $\mathrm{Fe}(\mathrm{II})$ produced over $100 \mathrm{~h}$ of incubation in ferrihydrite systems was measured. The concentration of total Fe(II) (sum of aqueous and adsorbed components) increased during the reaction period at all $\mathrm{Ca}$ concentrations and reached a value of $0.16 \pm 0.01 \mathrm{mM}$ for all $\mathrm{Ca}$ concentrations (including no $\mathrm{Ca}$ ) after $100 \mathrm{~h}$ of reaction. This concentration and rate are comparable to previous studies (Wielinga et al., 2000). Above, we report an increase in $\mathrm{Fe}_{(\mathrm{aq})}$ for $0.8 \mathrm{mM}$ Ca compared to $0 \mathrm{mM} \mathrm{Ca}$ but this did not appear until $>500 \mathrm{~h}$ (Stewart et al., 2007).

\section{Time-Dependence of U(VI) Reduction.}

Uranium is removed from solution via reduction by S. putrefaciens with subsequent precipitation of biogenic $\mathrm{UO}_{2}$ (s) in all systems studied but at varying rates. The rate of $\mathrm{U}$ removed from solution (expressed as the fraction of initial $\mathrm{U}$ ) conforms to a first-order rate expression (Figure 5). Pseudo first-order rate constants, $k\left(\mathrm{~h}^{-1}\right)$, are larger for systems without than those with $\mathrm{Ca}$ (Table 4), with the variation being most pronounced for the iron (hydr)oxide-free system where the rate constant decreases from $13.7 \pm 0.3\left(\times 10^{-3}\right) \mathrm{h}^{-1}$ in the absence of Ca to $0.8 \pm 0.0\left(\times 10^{-3}\right) \mathrm{h}^{-1}$ when $0.8 \mathrm{mM} \mathrm{Ca}$ is added to the system. It follows that the rate constant in the presence of ferrihydrite changes the least, ranging from $4.1 \pm 0.2\left(\mathrm{x} 10^{-3}\right) \mathrm{h}^{-1}$ for $0 \mathrm{mM} \mathrm{Ca}$ to $2.4 \pm 0.2\left(\mathrm{x} 10^{-3}\right)$ $\mathrm{h}^{-1}$ for $0.8 \mathrm{mM} \mathrm{Ca}$. Pseudo first-order rate constants (Table 2) are linearly correlated to calcium concentrations between 0 and $1 \mathrm{mM}$ (Figure 5). The above mentioned rate constants derived from a simple kinetic analysis are consistent with the full biogeochemical model results. 


\section{Simulation Results}

Simulations of no-ferrihydrite experiments show relatively good fits to the measured data suggesting that the conceptual model used for, and particularly the rate dependence of, U(VI) reduction on aqueous $\mathrm{UO}_{2}{ }^{2+}$ speciation (Equation 9) interpret the data well (Figure 6). In some cases, particularly at later times (i.e. $>70 \mathrm{~h}$ ) for the $0 \mathrm{mM} \mathrm{Ca}$ and $0.4 \mathrm{mM} \mathrm{Ca}$ experiments, the simulation over predicts $\mathrm{U}(\mathrm{VI})$ reduction. This indicates that the dependence of $\mathrm{U}(\mathrm{VI})$ reduction on the no-Ca $\mathrm{UO}_{2}{ }^{2+}$ species is not precisely described by the first-order expression shown in Equation 9. Additional simulations (not shown) indicate that the model is sensitive to the exponent $x_{1}$, with a change from 1 to 1.05 making a noticeable difference in the results (i.e. up to $0.025 \mathrm{mM}$ ). The sensitivity to this parameter highlights the rate dependence on the concentration of $\mathrm{UO}_{2}{ }^{2+}$ species. However, we have used the same rate expressions and parameters for each simulation to highlight the effects of the change in Ca concentrations in the no-ferrihydrite experiments, and the competition between Fe(III) reduction and U(VI) reduction in the withferrihydrite experiments. As a result, slight differences in the rates between the experiments will not be captured by the simulations.

At early times in the no-ferrihydrite experiments $(<10 \mathrm{~h})$ the experimental results show a sharp decline in the $U_{(a q)}$ concentrations followed by a slight rebound that is not represented by the simulations. This behavior is likely attributed to rapid microbial reduction, followed by reoxidation, before aqueous uranium begins to decrease at a more constant rate than is captured by the model. 
In general, simulations of the with-ferrihydrite experiments predict the experimental data reasonably well, with the slight exception of the $0.8 \mathrm{mM} \mathrm{Ca}$ experiment (Figure 7). The good agreement between the simulated and measured data suggests that the conceptual model captures the important features of the geochemical system.

\section{Discussion}

\section{Influence of Ca on U(VI) Reduction}

There are several possible mechanisms by which Ca may diminish uranium reduction. First, $\mathrm{Ca}$ may render the reduction of uranyl less thermodynamically favorable. Second, Ca may kinetically limit reduction by yielding a dominant complex that either has poor-orbital overlap with the uranium reductase or hinders site accessibility. Finally, Ca could have a toxic affect on the microorganisms. Previous studies have eliminated the possibility of toxic effects of $\mathrm{Ca}$ or $\mathrm{Ca}-\mathrm{U}-\mathrm{CO}_{3}$ to the bacteria (Brooks et al., 2003). Thermodynamic considerations illustrate that there is less than $10 \%$ difference in energy gained between the reduction of uranyl-carbonato and uranyl-calcium-carbonato species (Table 3). The Gibb's free energy of reaction $\left(\Delta G_{\mathrm{rxn}}\right)$ for reduction of $\left(\mathrm{UO}_{2}\right)_{2} \mathrm{CO}_{3}(\mathrm{OH})_{3}{ }^{-}\left(-157.3 \mathrm{~kJ} \mathrm{~mol}^{-1}\right)$, the dominant aqueous species in the absence of calcium, and $\mathrm{Ca}_{2} \mathrm{UO}_{2}\left(\mathrm{CO}_{3}\right)_{3}\left(-144.0 \mathrm{~kJ} \mathrm{~mol}^{-1}\right)$, the dominant species in the presence of calcium, are only $8 \%$ different — and both are highly favorable. Moreover, even with a Ca concentrations of $1 \mathrm{mM}$, the free energy of reaction for reduction of $\mathrm{U}(\mathrm{VI})$ is comparable to the energy yield from the reduction of ferrihydrite (under the conditions of this study). This gives rise to the hypothesis that the reduction of $\mathrm{U}(\mathrm{VI})$ by $S$. putrefaciens may have an unfavorable orbital symmetry, be sterically hindered, or have a high activation energy associated with uranylcalcium-carbonato complex dissociation. This phenomenon appears to extends to chemical 
reduction of $\mathrm{U}(\mathrm{VI})$ by $\mathrm{Fe}(\mathrm{II})$ in the presence of the $\mathrm{Ca}-\mathrm{U}-\mathrm{CO}_{3}$ complexes as noted by Nico et al. (2009) and Stewart et al. (2009)

\section{Rate Determining Steps in U(VI) Reduction}

Although a multitude of U(VI) species reside under the conditions evaluated within this study, there are two dominant species, $\mathrm{Ca}_{2} \mathrm{UO}_{2}\left(\mathrm{CO}_{3}\right)_{3}$ and $\left(\mathrm{UO}_{2}\right)_{2} \mathrm{CO}_{3}(\mathrm{OH})_{3}{ }^{-}$, under the geochemical conditions of this study; a third species, $\mathrm{UO}_{2}\left(\mathrm{CO}_{3}\right)_{2}{ }^{2-}$, resides at appreciable fractions of the total uranium. This allows for a simplified kinetic analysis as compared to the one above (Model Development Section). Considering these three species, reduction reactions coupled with lactate oxidation (Table 1) are described by the stoichiometries of reactions 1 to 3 .

$$
\begin{aligned}
& \mathrm{C}_{3} \mathrm{H}_{5} \mathrm{O}_{3}{ }^{-}+\left(\mathrm{UO}_{2}\right)_{2} \mathrm{CO}_{3}(\mathrm{OH})_{3}{ }^{-} \rightarrow \mathrm{C}_{2} \mathrm{H}_{3} \mathrm{O}_{2}{ }^{-}+2 \mathrm{HCO}_{3}{ }^{-}+2 \mathrm{UO}_{2}+\mathrm{H}_{2} \mathrm{O}+\mathrm{H}^{+} \\
& { }_{1} \mathrm{C}_{3} \mathrm{H}_{5} \mathrm{O}_{3}{ }^{-}+\mathrm{UO}_{2}\left(\mathrm{CO}_{3}\right)_{2}{ }^{2-}+\mathrm{H}_{2} \mathrm{O} \rightarrow{ }^{1}{ }_{2} \mathrm{C}_{2} \mathrm{H}_{3} \mathrm{O}_{2}{ }^{-}+{ }^{5} / 2 \mathrm{HCO}_{3}{ }^{-}+\mathrm{UO}_{2}+{ }^{1}{ }_{2} \mathrm{H}^{+} \\
& { }_{1} \mathrm{C}_{3} \mathrm{H}_{5} \mathrm{O}_{3}{ }^{-}+\mathrm{Ca}_{2} \mathrm{UO}_{2}\left(\mathrm{CO}_{3}\right)_{3}+\mathrm{H}_{2} \mathrm{O}+{ }^{1} /{ }_{2} \mathrm{H}^{+} \rightarrow{ }^{1}{ }_{2} \mathrm{C}_{2} \mathrm{H}_{3} \mathrm{O}_{2}{ }^{-}+{ }^{7} / 2 \mathrm{HCO}_{3}{ }^{-}+\mathrm{UO}_{2}+2 \mathrm{Ca}^{2+}
\end{aligned}
$$

Given that the reactions are unidirectional, the $\mathrm{pH}$ was maintained constant, and U(VI) reduction proceeds independent of lactate (enzyme substrate) concentration under the conditions and reaction period studied (Figure 3), the operative rate determining, microbially-mediated, reduction reactions can be simply expressed:

$$
\begin{aligned}
& \left(\mathrm{UO}_{2}\right)_{\mathrm{x}}\left(\mathrm{CO}_{3}\right)_{\mathrm{y}}(\mathrm{aq}) \stackrel{k_{1}}{\longrightarrow} \mathrm{UO}_{2(\mathrm{~s})} \\
& \mathrm{Ca}_{2} \mathrm{UO}_{2}\left(\mathrm{CO}_{3}\right)_{3(\mathrm{aq})} \stackrel{k_{2}}{\longrightarrow} \mathrm{UO}_{2(\mathrm{~s})}
\end{aligned}
$$


where in reaction $4\left(\mathrm{UO}_{2}\right)_{\mathrm{x}}\left(\mathrm{CO}_{3}\right)_{\mathrm{y}}$ represents the combined contributions of the carbonato species $\left(\mathrm{UO}_{2}\right)_{2} \mathrm{CO}_{3}(\mathrm{OH})_{3}{ }^{-}$and $\mathrm{UO}_{2}\left(\mathrm{CO}_{3}\right)_{2}{ }^{2-}$, both of which are present in appreciable proportions under the reaction conditions examined.

Under conditions where the ternary calcium complex of U(VI) dominates the aqueous speciation, reduction may proceed either by reaction 5 or through the small proportion of carbonato complexes without calcium (reaction 4). In the latter case, inter-species conversion must then be described as well,

$$
\mathrm{Ca}_{2} \mathrm{UO}_{2}\left(\mathrm{CO}_{3}\right)_{3}+\mathrm{H}^{+} \underset{k_{-3}}{\stackrel{k_{3}}{\rightleftarrows}} \mathrm{UO}_{2}\left(\mathrm{CO}_{3}\right)_{2}{ }^{2-}+\mathrm{HCO}_{3}^{-}+2 \mathrm{Ca}^{2+}
$$

Given the excess concentration of bicarbonate and calcium relative to uranium, and the constant $\mathrm{pH}$, the inter-species conversion simplifies to:

$$
\mathrm{Ca}_{2} \mathrm{UO}_{2}\left(\mathrm{CO}_{3}\right)_{3} \underset{k_{-3}}{\stackrel{k_{3}}{\rightleftarrows}} \mathrm{UO}_{2}\left(\mathrm{CO}_{3}\right)_{2}{ }^{2-}
$$

The reactions expressed in reactions 4 and 5 thus appear to represent the rate controlling processes for uranyl reduction, with inter-conversion of uranyl species potentially important within $\mathrm{Ca}$ containing solutions. On the basis of $\mathrm{U}(\mathrm{VI})$ reduction rates in the presence and absence of $\mathrm{Ca}$, reaction 4 proceeds at a much faster rate than reaction 5 (i.e., $k_{1}>>k_{2}$ ). With the selective removal of the carbonato complexes, reaction 6 would proceed in the forward direction during reduction. Reaction 4 thus expresses the rate controlling reaction for non-Ca bearing solutions, while reaction 5 and the coupling of reactions 4 and 6 would operate in series (reaction 7) as the rate influencing reactions in Ca-bearing solutions. 


$$
\mathrm{Ca}_{2} \mathrm{UO}_{2}\left(\mathrm{CO}_{3}\right)_{3} \stackrel{k_{3}}{\longrightarrow} \mathrm{UO}_{2}\left(\mathrm{CO}_{3}\right)_{2}{ }^{2-} \stackrel{k_{1}}{\longrightarrow} \mathrm{UO}_{2(\mathrm{~s})}
$$

This correlates well with simulation results that indicate the reduction rate constant for uranylcarbonato species, $\mathrm{k}_{1}=7.5 \times 10^{-6} \mathrm{~s}^{-1}$, is more than 10 times the rate constant for uranyl-calciumcarbonato complexes, $\mathrm{k}_{1 \mathrm{~b}}=3.1 \times 10^{-7} \mathrm{~s}^{-1}$, suggesting that the rate of reduction of uranyl-calciumcarbonato complexes is appreciably lower but not zero.

\section{Impact of Fe(III) (hydr)oxides on U(VI) Reduction}

Ferric (hydr)oxides impart an interesting complexity on uranium reduction. On the one hand, they can serve as competing electron acceptors of $\mathrm{U}(\mathrm{VI})$ and as oxidants of $\mathrm{U}(\mathrm{IV})$ (under specific reaction conditions) (Figure 1). On the other hand, they can also regulate the dissolved concentration of $\mathrm{Ca}$, decreasing the proportion of the $\mathrm{Ca}-\mathrm{U}$ ternary complex, and enhancing $\mathrm{U}(\mathrm{VI})$ reduction.

Ferrihydrite has the highest redox potential of the Fe(III) phases investigated here, and indeed it is the only Fe(III) (hydr)oxide to decrease the extent of $\mathrm{U}(\mathrm{VI})$ reduction. As noted above, ferrihydrite may either compete as an electron acceptor in microbial respiration or may act as an oxidant of biogenic $\mathrm{UO}_{2}$. A series of recent reports indicate reoxidation of uraninite by $\mathrm{Fe}(\mathrm{III})$ at high concentrations of $\mathrm{HCO}_{3}{ }^{-}$resulting from bacterial respiration (Sani et al., 2005; Senko et al., 2005; Wan, 2005). However, under the conditions of our study $\left(\mathrm{HCO}_{3}{ }^{-}<6 \mathrm{mM}, 0.168 \mathrm{U}(\mathrm{VI})\right.$, and $\mathrm{pH}$ 7), even the oxidation of biogenic $\mathrm{UO}_{2}$ to $\mathrm{Ca}_{2} \mathrm{UO}_{2}\left(\mathrm{CO}_{3}\right)_{3}$ by ferrihydrite, the most viable reaction, would be thermodynamically favorable only at $\mathrm{Fe}(\mathrm{II})$ concentrations less than 0.025 $\mathrm{mM} \mathrm{Fe}(\mathrm{II})$ during the initial stages of reduction and $0.050 \mathrm{mM}$ at late stages. These $\mathrm{Fe}(\mathrm{II})$ values 
are exceeded during the initial stages of reaction $(\mathrm{t}<100 \mathrm{~h}$ ) and reoxidation of $\mathrm{U}(\mathrm{IV})$ therefore does not appear operative in this system.

Ferrihydrite, however, is not a static phase during Fe(II) production and instead undergoes a cascade of secondary reactions, dominantly leading to goethite or magnetite depending on the Fe(II) concentrations (Hansel et al., 2004). With progressive incubation, the ferrihydrite system responds in a similar way to goethite and hematite, consistent with a shift in mineralogy from ferrihydrite to goethite during dissimilatory iron reduction (Hansel et al., 2003, 2004). Hansel et al. (2003) report a threshold limit of $0.4 \mathrm{mmol} \mathrm{Fe(II)/g-ferrihydrite} \mathrm{below} \mathrm{which} \mathrm{ferrihydrite}$ converts via Oswald ripening primarily to goethite/lepidocrocite and above which it converts to both goethite and magnetite. Iron(II) levels produced in the ferrihydrite system do not exceed this threshold when $\mathrm{Ca}$ is present until $171 \mathrm{~h}(0.52 \mathrm{mM}, 1.3 \mathrm{mmol} \mathrm{Fe}(\mathrm{II}) / \mathrm{g}$-ferrihydrite), and would therefore lead to pronounced generation of goethite.

In addition to serving as a competing electron acceptor, Fe(III) (hydr)oxides influence U(VI) reduction through adsorption of $\mathrm{Ca}$, diminishing its aqueous concentrations and thereby decreasing the proportion of the apparently less reactive $\mathrm{Ca}_{2} \mathrm{UO}_{2}\left(\mathrm{CO}_{3}\right)_{3}$ species. The impact is pronounced with goethite and hematite (Figure 3). Thus, the inhibitory effect of Ca on U(VI) reduction may be diminished when competing sinks for $\mathrm{Ca}$ are present; ultimately, the dissolved concentration of $\mathrm{Ca}$ in equilibrium with the uranyl species is the controlling factor. Finally, all of the Fe(III) (hydr)oxides, and ferrihydrite in particular, have an intriguing impact on U(VI) reduction in the presence of $\mathrm{Ca}$. While ferrihydrite acts as a competing electron acceptor for microbial reduction of $\mathrm{U}(\mathrm{VI})$, as $\mathrm{Ca}$ concentrations increase, $\mathrm{U}(\mathrm{VI})$ reduction is promoted (rather 
than retarded) in systems with ferrihydrite as compared to those without. Under the specific geochemical conditions in this study, ferrihydrite does not impact the rate or extent of uranium reduction during the first $100 \mathrm{~h}$ of incubation without $\mathrm{Ca}$. In systems containing $\mathrm{Ca}$, however, ferrihydrite appears to increase rates of U(VI) reduction compared to systems without ferrihydrite; at Ca concentrations $>0.4 \mathrm{mM}$, however, uranium reduction rate becomes independent of Ca concentration. This gives rise to two hypotheses on ferrihydrite's influence. One possibility is that $\mathrm{Ca}$ is adsorbing to the surface of ferrihydrite, offsetting equilibrium with the uranyl-calcium-carbonato complexes. However, aqueous measurements indicate that $\mathrm{Ca}$ concentrations are identical in systems with and without ferrihydrite. A second, more substantiative explanation is that ferrihydrite adsorbs both free-uranyl and uranyl-carbonato complexes that are subject to microbial or Fe(II)-induced (Liger et al., 1999) reduction. In this scenario, $\mathrm{Ca}$ (aq) competes with the surface of ferrihydrite for uranyl and uranyl-carbonato species, with the Ca complexed uranium having a diminished reduction rate compared to free or adsorbed uranium. More information on changes in uranyl speciation in the presence of solid phases is provided in Stewart et., (2010).

\section{Implications for Uranium Reduction and Mobility}

Despite the observation of uranium(VI) reduction and subsequent precipitation of $\mathrm{UO}_{2}$, both the rate and extent of reduction in complex geochemical settings are potentially diminished by aqueous and solid phase constituents of soils and sediments. The presence of calcium in carbonate-bearing solutions promotes the formation of ternary complexes, $\mathrm{Ca}_{2} \mathrm{UO}_{2}\left(\mathrm{CO}_{3}\right)_{3}$ and $\mathrm{CaUO}_{2}\left(\mathrm{CO}_{3}\right)_{3}{ }^{2-}$, which have a profound impact on $\mathrm{U}$ biogeochemistry by decreasing both microbial and abiotic reduction rates. Iron (hydr)oxides, in contrast, have non-linear effects on 
$\mathrm{U}(\mathrm{VI})$ reduction. Goethite and hematite act as sorbents of $\mathrm{Ca}$, and as a result decrease the proportion of the less reducible $\mathrm{Ca}_{2} \mathrm{UO}_{2}\left(\mathrm{CO}_{3}\right)_{3}$ species. At higher calcium concentrations, ferrihydrite has the ability to mitigate speciation changes invoked by the predominance of these complexes, thus increasing the rate of microbial reduction of uranium compared to systems with no ferrihydrite. Ultimately, U(VI) speciation, induced by both aqueous constituents particularly the formation of $\mathrm{Ca}-\mathrm{UO}_{2}-\mathrm{CO}_{3}$ complexes and equilibrium solid phases, the presence of competing terminal electron acceptors, and potential oxidants, will control the rate and extent of reduction.

\section{Acknowledgments}

We would like to thank Shawn Benner for his constructive input on this manuscript, Jim Neiss for experimental assistance, and Guangchao Li for assisting with experimental measurements. This work was funded by the Environmental Remediation Science Program, Office of Biological and Environmental Science, U.S. Department of Energy (grant number ER63609-1021814), by the Stanford NSF Environmental Molecular Sciences Institute (NSF-CHE-0431425), and in part by the U.S. Department of Energy, Office of Science, Office of Biological and Environmental Resources as part of the Subsurface Science Scientific Focus Area under Contract Number DEAC02-05CH11231. 


\section{References}

Abdelouas A, Lutze W, Nuttall E. 1998a. Chemical reactions of uranium in ground water at a mill tailings site. J Contam Hydro 34:343-361.

Abdelouas A, Lutze W, Nuttall E. 1998b. Reduction of nitrate and uranium by indigenous bacteria. Comptes Rendus de l'Academie des Sciences Serie II A Sciences de la Terre et des Planetes 327:25-29.

Allison JD, Brown DS, Novo-Gradac KJ. 1991. MINTEQA2/PRODEFA2, A geochemical assessment model for environmental systems: Version 3.0 User's Manual. Washington, DC: U.S. Environmental Protection Agency. Report nr EPA/600/3-91/021.

Anderson RT, Vrionis HA, Ortiz-Bernad I, Resch CT, Long PE, Dayvault R, Karp K, Marutzky S, Metzler DR, Peacock A and others. 2003. Stimulating the in situ activity of Geobacter species to remove uranium from the groundwater of a uranium-contaminated aquifer. Appl Environ Microbiol 69:5884-5891.

Atkinson RJ, Posner AM, Quirk JP. 1967. Adsorption of potential-determining ions at ferric oxide-aqueous electrolyte interface. J Phys Chem 71:550-\&.

Ball JW, Nordstrom DK. 1991. User's Manual for WATEQ4F, with revised thermodynamic database and test cases for calculating speciation of major, trace and redox elements in natural waters. Reston, VA: USGS. Report nr 91-183.

Bernhard G, Geipel G, Brendler V, Nitsche H. 1996. Speciation of uranium in seepage waters of a mine tailing pile studied by time-resolved laser-induced fluorescence spectroscopy (TRLFS). Radiochim Act 74:87-91. 
Bernhard G, Geipel G, Reich T, Brendler V, Amayri S, Nitsche H. 2001. Uranyl(VI) carbonate complex formation: Validation of the $\mathrm{Ca}_{2} \mathrm{UO}_{2}\left(\mathrm{CO}_{3}\right)_{(3)(\text { (aq.) }}$ species. Radiochim Act 89:511518.

Brooks SC, Carroll SL, Jardine PM. 1999. Sustained bacterial reduction of Co(III)EDTA(-) in the presence of competing geochemical oxidation during dynamic flow. Environ Sci Technol 33:3002-3011.

Brooks SC, Fredrickson JK, Carroll SL, Kennedy DW, Zachara JM, Plymale AE, Kelly SD, Kemner KM, Fendorf S. 2003. Inhibition of bacterial U(VI) reduction by calcium. Environ Sci Technol 37:1850-1858.

Brooks SC, Taylor DL, Jardine PM. 1996. Reactive transport of EDTA-complexed cobalt in the presence of ferrihydrite. Geochim Cosmochim Act 60:1899-1908.

Clark DL, Hobart DE, Neu MP. 1995. Actinide carbonate complexes and their importance in actinide environmental chemistry. Chem Rev 95:25-48.

DiChristina TJ, Fredrickson JK, Zachara JM. 2005. Enzymology of electron transport: energy generation with geochemical consequences. In: Banfield J, CerviniSilva J, Nealson K, editors. Molecular Geomicrobiology. Minerological Society of America. P 27-52.

Dong WM, Brooks SC. 2006. Determination of the formation constants of ternary complexes of uranyl and carbonate with alkaline earth metals $\left(\mathrm{Mg}^{2+}, \mathrm{Ca}^{2}+\mathrm{Sr}^{2+}\right.$, and $\left.\mathrm{Ba}^{2+}\right)$ using anion exchange method. Environ Sci Technol 40:4689-4695.

Fox PM, Davis JA, Zachara JM. 2006. The effect of calcium on aqueous uranium(VI) speciation and adsorption to ferrihydrite and quartz. Geochim Cosmochim Act 70:1379-1387. 
Fredrickson JK, Zachara JM, Kennedy DW, Duff MC, Gorby YA, Li SMW, Krupka KM. 2000. Reduction of $\mathrm{U}(\mathrm{VI})$ in goethite (alpha-FeOOH) suspensions by a dissimilatory metalreducing bacterium. Geochim Cosmochim Act 64:3085-3098.

Ganesh R, Robinson KG, Reed GD, Sayler GS. 1997. Reduction of hexavalent uranium from organic complexes by sulfate- and iron-reducing bacteria. Appl Environ Microbiol 63:4385-4391.

Ginder-Vogel M, Criddle CS, Fendorf S. 2006. Thermodynamic constraints on the oxidation of biogenic $\mathrm{UO}_{2}$ by Fe(III) (hydr) oxides. Environ Sci Technol 40:3544-3550.

Gorby YA, Lovley DR. 1992. Enzymatic uranium precipitation. Environ Sci Technol 26:205207.

Guillaumont R, Fanghanel T, Neck V, Fuger J, Palmer DA, Grenthe I, Rand MH. 2003. Update on the chemical thermodynamics of uranium, neptunium, plutonium, americium, and technichium. Paris, France: Nuclear Energy Agency.

Hansel CM, Benner SG, Neiss J, Dohnalkova A, Kukkadapu RK, Fendorf S. 2003. Secondary mineralization pathways induced by dissimilatory iron reduction of ferrihydrite under advective flow. Geochim Cosmochim Act 67:2977-2992.

Hansel CM, Benner SG, Nico P, Fendorf S. 2004. Structural constraints of ferric (hydr)oxides on dissimilatory iron reduction and the fate of Fe(II). Geochim Cosmochim Act 68:32173229.

Kalmykov SN, Choppin GR. 2000. Mixed $\mathrm{Ca}^{2+} / \mathrm{UO}_{2}{ }^{2+} / \mathrm{CO}_{3}{ }^{2-}$ complex formation at different ionic strengths. Radiochim Act 88:603-606. 
Kelly S, Kemner KM, Brooks SC, Fredrickson JK, Kennedy DW, Zachara JM, Fendorf S, Plymale A, Carroll SL. 2003. Direct evidence for $\mathrm{Ca}-\mathrm{UO}_{2}-\mathrm{CO}_{3}$ complexation. Abstr Pap Am Chem S 225:U256.

Liger E, Charlet L, Van Cappellen P. 1999. Surface catalysis of uranium(VI) reduction by iron(II). Geochim Cosmochim Act 63:2939-2955.

Liu CX, Gorby YA, Zachara JM, Fredrickson JK, Brown CF. 2002. Reduction kinetics of $\mathrm{Fe}(\mathrm{III}), \mathrm{Co}(\mathrm{III}), \mathrm{U}(\mathrm{VI}), \mathrm{Cr}(\mathrm{VI})$, and $\mathrm{Tc}(\mathrm{VII})$ in cultures of dissimilatory metal-reducing bacteria. Biotech Bioeng 80:637-649.

Lovley DR. 1991. Dissimilatory Fe(III) and Mn(IV) reduction. Microbiol Rev 55:259-287.

Luo J, Weber FA, Cirpka OA, Wu WM, Nyman JL, Carley J, Jardine PM, Criddle CS, Kitanidis PK. 2007. Modeling in-situ uranium(VI) bioreduction by sulfate-reducing bacteria. J Contam Hydro 92:127-146.

Mayer KU, Frind EO, Blowes DW. 2002. Multicomponent reactive transport modeling in variably saturated porous media using a generalized formulation for kinetically controlled reactions. Water Resour Res 38:1174.

Meleshyn A, Azeroual M, Reeck T, Houben G, Riebe B, Bunnenberg C. 2009. Influence of calcium-uranyl-carbonate complexation on $\mathrm{U}(\mathrm{VI})$ sorption on $\mathrm{Ca}$ - and Na-bentonites. Environ Sci Technol 43:4896-4901.

Michalsen MM, Goodman BA, Kelly SD, Kemner KM, McKinley JP, Stucki JW, Istok JD. 2006. Uranium and technetium bio-immobilization in intermediate-scale physical models of an in situ bio-barrier. Environ Sci Technol 40:7048-7053.

Moon HS, Komlos J, Jaffe PR. 2007. Uranium reoxidation in previously bioreduced sediment by dissolved oxygen and nitrate. Environ Sci Technol 41:4587-4592. 
Neiss J, Stewart BD, Nico PS, Fendorf S. 2007. Speciation-dependent microbial reduction of uranium within iron-coated sands. Environ Sci Technol 41:7343-7348.

Nico PS, Stewart BD, Fendorf S. 2009. Incorporation of oxidized uranium into Fe (hydr)oxides during Fe(II) Catalyzed Remineralization. Environ Sci Technol 43:7391-7396.

Payne RB, Gentry DA, Rapp-Giles BJ, Casalot L, Wall JD. 2002. Uranium reduction by Desulfovibrio desulfuricans strain G20 and a cytochrome c3 mutant. Appl Environ Microbiol 68:3129-3132.

Sani RK, Peyton BM, Dohnalkova A, Amonette JE. 2005. Reoxidation of reduced uranium with iron(III) (Hydr)oxides under sulfate-reducing conditions. Environ Sci Technol 39:20592066.

Schwertmann U, Cornell, RM. 2000. Iron Oxides in the Laboratory Preparation and Characterization. Second Edition. Wiley-VCH.

Senko JM, Mohamed Y, Dewers TA, Krumholz LR. 2005. Role for Fe(III) minerals in nitratedependent microbial U(IV) oxidation. Environ Sci Technol 39:2529-2536.

Spear JR, Figueroa LA, Honeyman BD. 2000. Modeling reduction of uranium U(VI) under variable sulfate concentrations by sulfate-reducing bacteria. Appl Environ Microb $66: 3711-3721$.

Stewart BD, Mayes MA, Fendorf S. 2010. Impact of uranyl-calcium-carbonato complexes on uranium(VI) adsorption to synthetic and natural sediments. Environ Sci Technol 44:928934.

Stewart BD, Neiss J, Fendorf S. 2007. Quantifying constraints imposed by calcium and iron on bacterial reduction of uranium(VI). J Environ Qual 36:363-372. 
Stewart BD, Nico PS, Fendorf S. 2009. Stability of uranium incorporated into Fe (hydr)oxides under fluctuating redox conditions. Environ Sci Technol 43:4922-4927.

Stookey LL. 1970. A new spectrophotometric reagent for iron. Anal Chem 42:779-781.

Vangeen A, Robertson AP, Leckie JO. 1994. Complexation of carbonate species at the goethite surface - implications for adsorption of metal -ions in natural waters. Geochim Cosmochim Act 58:2073-2086.

Wan JM, Tokunaga TK, Brodie E, Wang ZM, Zheng ZP, Herman D, Hazen TC, Firestone MK, Sutton SR. 2005. Reoxidation of bioreduced uranium under reducing conditions. Environ Sci Technol 39:6162-6169.

Wan JT, Tetsu K, Brodie E, Wang Z, Zheng Z, Herman D, Hazen TC, Firestone MK, Sutton SR. 2005. Reoxidation of bioreduced uranium under reducing conditions. Environ Sci Technol 39:6162 - 6169.

Wielinga B, Bostick B, Hansel CM, Rosenzweig RF, Fendorf S. 2000. Inhibition of bacterially promoted uranium reduction: ferric (hydr)oxides as competitive electron acceptors. Environ Sci Technol 34:2190-2195.

Wu WM, Carley J, Fienen M, Mehlhorn T, Lowe K, Nyman J, Luo J, Gentile ME, Rajan R, Wagner D and others. 2006a. Pilot-scale in situ bioremediation of uranium in a highly contaminated aquifer. 1. Conditioning of a treatment zone. Environ Sci Technol 40:39783985.

Wu WM, Carley J, Gentry T, Ginder-Vogel MA, Fienen M, Mehlhorn T, Yan H, Caroll S, Pace MN, Nyman J and others. 2006b. Pilot-scale in situ bioremedation of uranium in a highly contaminated aquifer. 2. Reduction of $\mathrm{U}(\mathrm{VI})$ and geochemical control of $\mathrm{U}(\mathrm{VI})$ bioavailability. Environ Sci Technol 40:3986-3995. 
Wu WM, Carley J, Luo J, Ginder-Vogel MA, Cardenas E, Leigh MB, Hwang CC, Kelly SD, Ruan CM, Wu LY and others. 2007. In situ bioreduction of uranium (VI) to submicromolar levels and reoxidation by dissolved oxygen. Environ Sci Technol 41:5716-5723. 


\section{Tables}

Table 1. Redox reactions for various $\mathrm{U}(\mathrm{VI})$ and $\mathrm{Fe}(\mathrm{III})$ species coupled with lactate oxidation (ferrihydrite, $\mathrm{Fe}(\mathrm{OH})_{3}$; goethite, $\mathrm{FeOOH}$; hematite, $\mathrm{Fe}_{2} \mathrm{O}_{3}$ ).

\section{Redox Reaction}

$\mathrm{C}_{3} \mathrm{H}_{5} \mathrm{O}_{3}{ }^{-}+4 \mathrm{Fe}(\mathrm{OH})_{3}+7 \mathrm{H}^{+} \rightarrow \mathrm{C}_{2} \mathrm{H}_{3} \mathrm{O}_{2}{ }^{-}+4 \mathrm{Fe}^{2+}+\mathrm{HCO}_{3}{ }^{-}+10 \mathrm{H}_{2} \mathrm{O}$
$\mathrm{C}_{3} \mathrm{H}_{5} \mathrm{O}_{3}{ }^{-}+4 \mathrm{FeOOH}+7 \mathrm{H}^{+} \rightarrow \mathrm{C}_{2} \mathrm{H}_{3} \mathrm{O}_{2}{ }^{-}+4 \mathrm{Fe}^{2+}+\mathrm{HCO}_{3}{ }^{-}+6 \mathrm{H}_{2} \mathrm{O}$

1) Majzlan et al. (2004)

2) Cornell and Schwertmann (2003)

3) Guillaumont et al. (2003)

4) Bernhard et al. (2001)

5) Dong et al. (2006) 
Table 2. Pseudo-first order rate coefficients $\left(k_{\mathrm{obs}}\right)$ at various calcium concentrations for the different Fe(III) (hydr)oxide systems.

\begin{tabular}{llccc}
$\mathbf{C a}$ & $\begin{array}{l}\text { Ferrihydrite } \\
\text { Ln } k_{o b s} \\
=-0.650(\mathrm{Ca})-5.56\end{array}$ & $\begin{array}{c}\text { Goethite } \\
\text { Ln } k_{o b s} \\
=-1.72(\mathrm{Ca})-4.55\end{array}$ & $\begin{array}{c}\text { Hematite } \\
\text { Ln } k_{o b s} \\
=-1.46(\mathrm{Ca})-4.72 \\
(\mathbf{m M})\end{array}$ & $\begin{array}{c}\text { Iron oxide-free } \\
\text { Ln } k_{o b s} \\
=-3.57(\mathrm{Ca})-4.46\end{array}$ \\
\hline $\mathbf{0}$ & $4.1 \pm 0.2$ & $11.9 \pm 0.6$ & $9.7 \pm 0.4$ & $13.7 \pm 0.3$ \\
$\mathbf{0 . 4}$ & $2.6 \pm 0.0$ & $4.6 \pm 0.0$ & $4.1 \pm 0.1$ & $2.0 \pm 0.1$ \\
$\mathbf{0 . 6}$ & $2.7 \pm 0.0$ & $3.1 \pm 0.0$ & $4.0 \pm 0.1$ & $1.3 \pm 0.1$ \\
$\mathbf{0 . 8}$ & $2.4 \pm 0.2$ & $3.3 \pm 0.5$ & $2.0 \pm 0.1$ & $0.8 \pm 0.0$
\end{tabular}

*Values having an associated error of 0.0 as the composite error are reported relative to the mean and these particular data points lie on the mean value. 
Table 3. Gibb's free energy of reaction $\left(\Delta \mathbf{G}_{\text {reaction }}{ }^{*}\right)$ for $\mathrm{Fe}(\mathrm{III})$ and $\mathrm{U}(\mathrm{VI})$ reduction coupled with lactate oxidation at varying $\mathrm{Ca}_{(\mathrm{aq})}$ concentrations. Values are calculated for dominant aqueous species as indicated in Table 2 and are adjusted for experimental conditions $(\mathrm{pH}=7$, $\left.\left[\mathrm{CO}_{3}\right]_{\mathrm{T}}=3.8 \mathrm{mM},[\mathrm{U}(\mathrm{VI})]=0.168 \mathrm{mM}\right)$.

\begin{tabular}{lccccc}
\multicolumn{5}{c}{$\Delta \mathbf{G}_{\text {reaction* }}(\mathbf{K J} / \mathbf{m o l})$} \\
\hline $\mathbf{F e}(\mathbf{O H})_{3} /$ lactate & -139.5 & -139.5 & -139.5 & -139.5 & -139.5 \\
$\mathbf{F e}_{2} \mathbf{O}_{3} /$ lactate & -58.27 & -58.27 & -58.27 & -58.27 & -58.27 \\
$\mathbf{C a}_{2} \mathbf{U O}_{2}\left(\mathbf{C O}_{3}\right)_{3} /$ lactate & & -148.3 & -145.9 & -143.8 & -142.1 \\
$\mathbf{U O}_{2}\left(\mathbf{C O}_{3}\right)_{2}{ }^{2-} /$ lactate & -158.8 & & & & \\
$\mathbf{U O}_{2}\left(\mathbf{C O}_{3}\right)_{3}{ }^{4-} /$ lactate & 42.91 & & & & \\
$\left(\mathbf{U O}_{2}\right) \mathbf{2 C O}_{3}(\mathbf{O H})_{3}{ }^{-} /$lactate & -158.60 & -156.07 & &
\end{tabular}




\section{Figure Captions}

Figure 1. $\mathrm{U}(\mathrm{VI}) / \mathrm{U}(\mathrm{IV})$ and $\mathrm{Fe}(\mathrm{III}) / \mathrm{Fe}(\mathrm{II})$ redox couples at $\mathrm{pH}=7,\left[\mathrm{CO}_{3}\right]_{\mathrm{T}}=3 \mathrm{mM}$, and $[\mathrm{Ca}]=1 \mathrm{mM}$ illustrating the overlapping nature of $\mathrm{U}$ and $\mathrm{Fe}$ redox couples.

Figure 2. Fractional species of $\mathrm{U}(\mathrm{VI})$ as a function of $\mathrm{Ca}$ concentration $(\mathrm{mM})$ depicted as the sum of $\mathrm{U}-\mathrm{CO}_{3}$ and $\mathrm{U}-\mathrm{Ca}-\mathrm{CO}_{3}$ species $\left(\mathrm{pH}=7,\left[\mathrm{CO}_{3}\right]_{\mathrm{T}}=3.8 \mathrm{mM}\right)$.

Figure 3. Temporal changes in uranyl concentration induced by S. putrefaciens at $\mathrm{Ca}$ concentrations ranging from 0 to $0.8 \mathrm{mM}$ in the presence of a) ferrihydrite, b) goethite, c) hematite and d) Fe -free system.

Figure 4. Temporal changes in $\mathrm{Fe}$ (aq) concentration induced by S. putrefaciens in the presence of ferrihydrite.

Figure 5. Relation between observed pseudo first-order rate coefficient and aqueous $\mathrm{Ca}$ concentrations for ferrihydrite, goethite, hematite, and $\mathrm{Fe}$ (hydr)oxide-free systems.

Figure 6. Aqueous phase $\mathrm{U}$ (individual species and total $\mathrm{U}$ ) during $\mathrm{U}(\mathrm{VI})$ reduction by $S$. putrefaciens with lactate as a function of time for systems containing (A) $0 \mathrm{mM} \mathrm{Ca}$, (B) $0.4 \mathrm{mM}$ Ca, (C) $0.6 \mathrm{mM} \mathrm{Ca}$, and (D) $0.8 \mathrm{mM} \mathrm{Ca}$. Experimental data are represented by squares and simulations by lines.

Figure 7. Aqueous phase $\mathrm{U}$ and total Fe(II) produced during $\mathrm{U}(\mathrm{VI})$ and $\mathrm{Fe}(\mathrm{III})$ (ferrihydrite) reduction by S. putrefaciens with lactate as a function of time for systems containing (A) $0 \mathrm{mM}$ Ca, (B) $0.4 \mathrm{mM} \mathrm{Ca}$, (C) $0.6 \mathrm{mM} \mathrm{Ca}$, and (D) $0.8 \mathrm{mM} \mathrm{Ca}$. Experimental data are represented by squares and simulations by lines. 
Figures

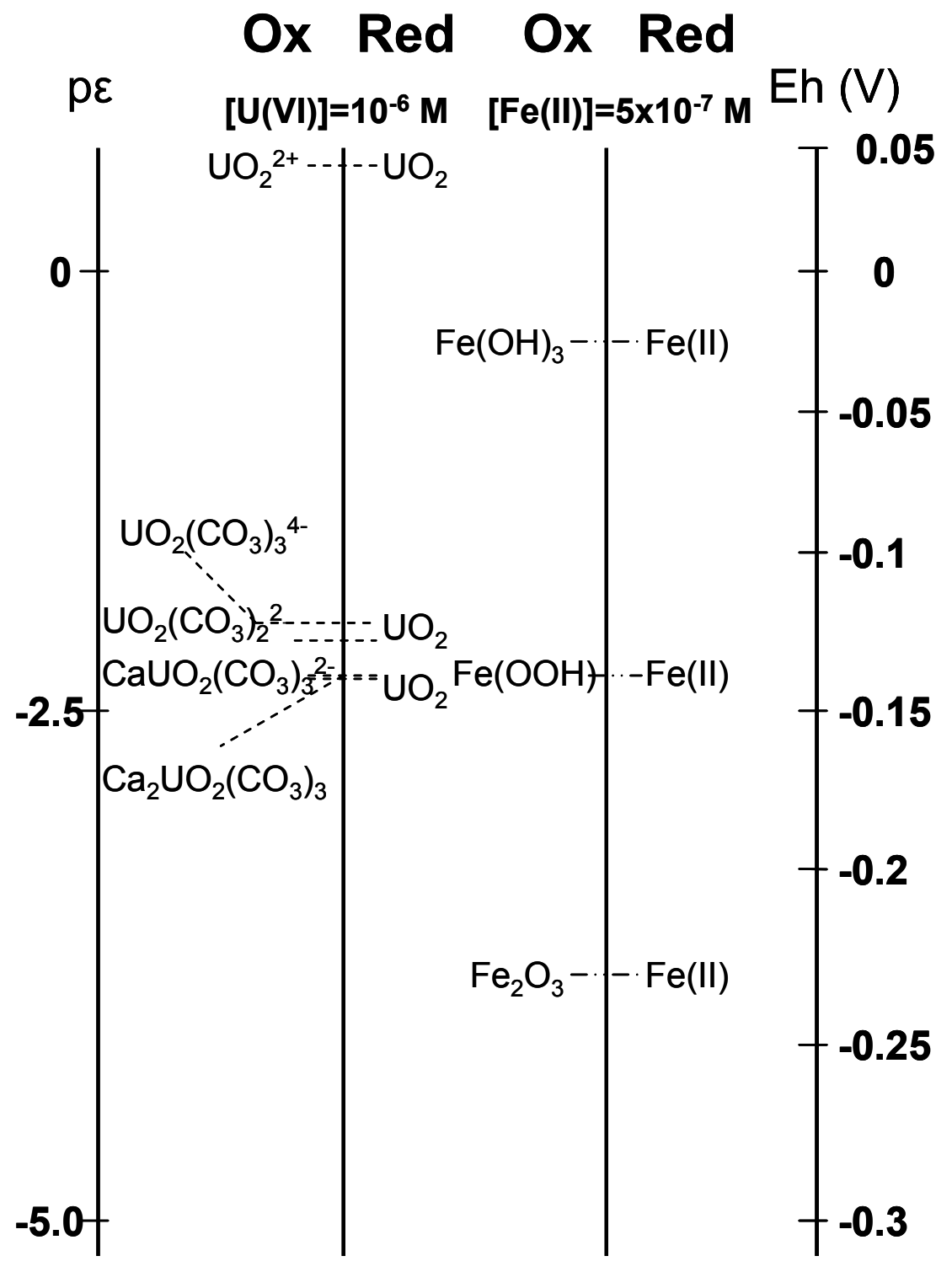

Figure 1. 


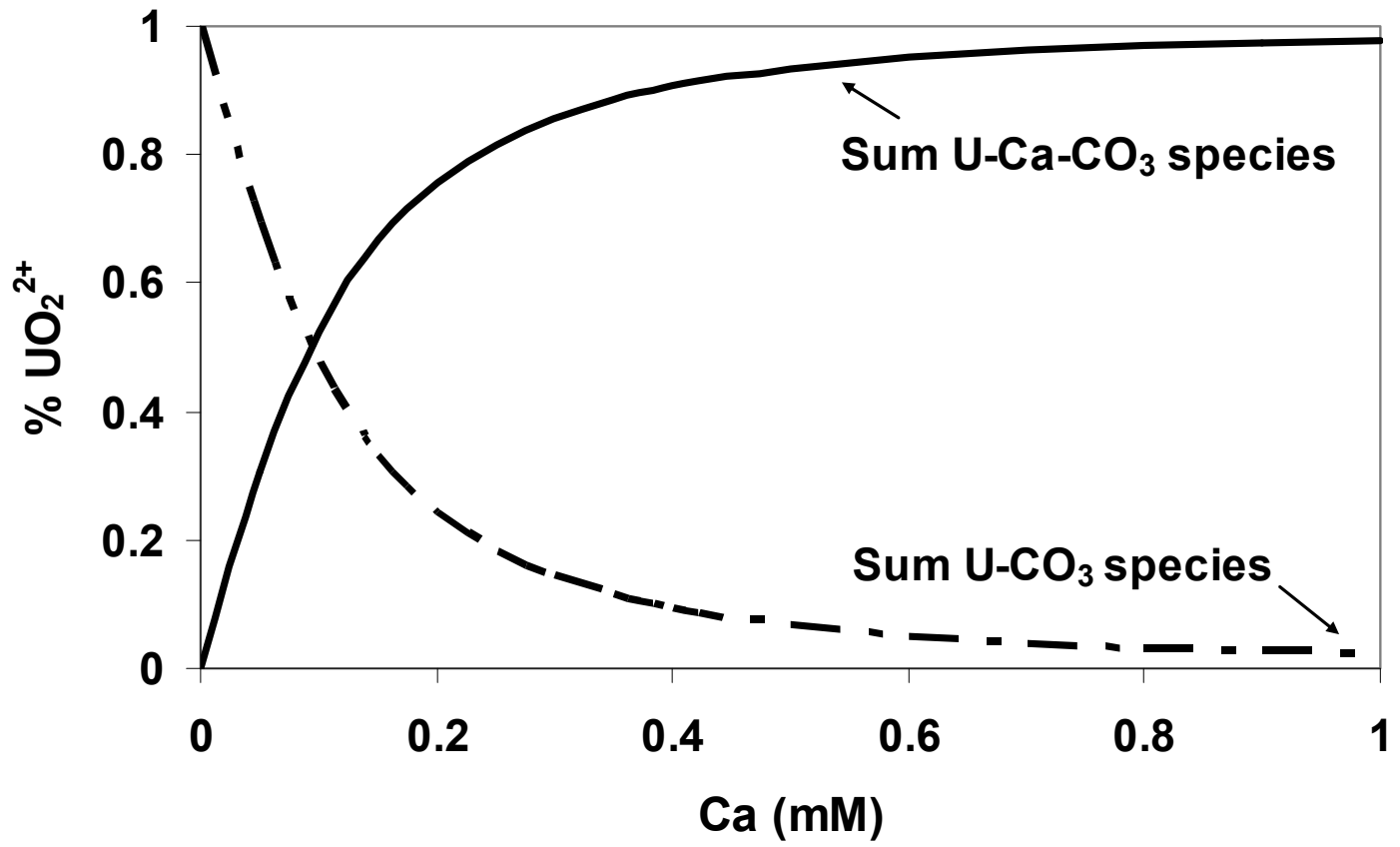

Figure 2. 

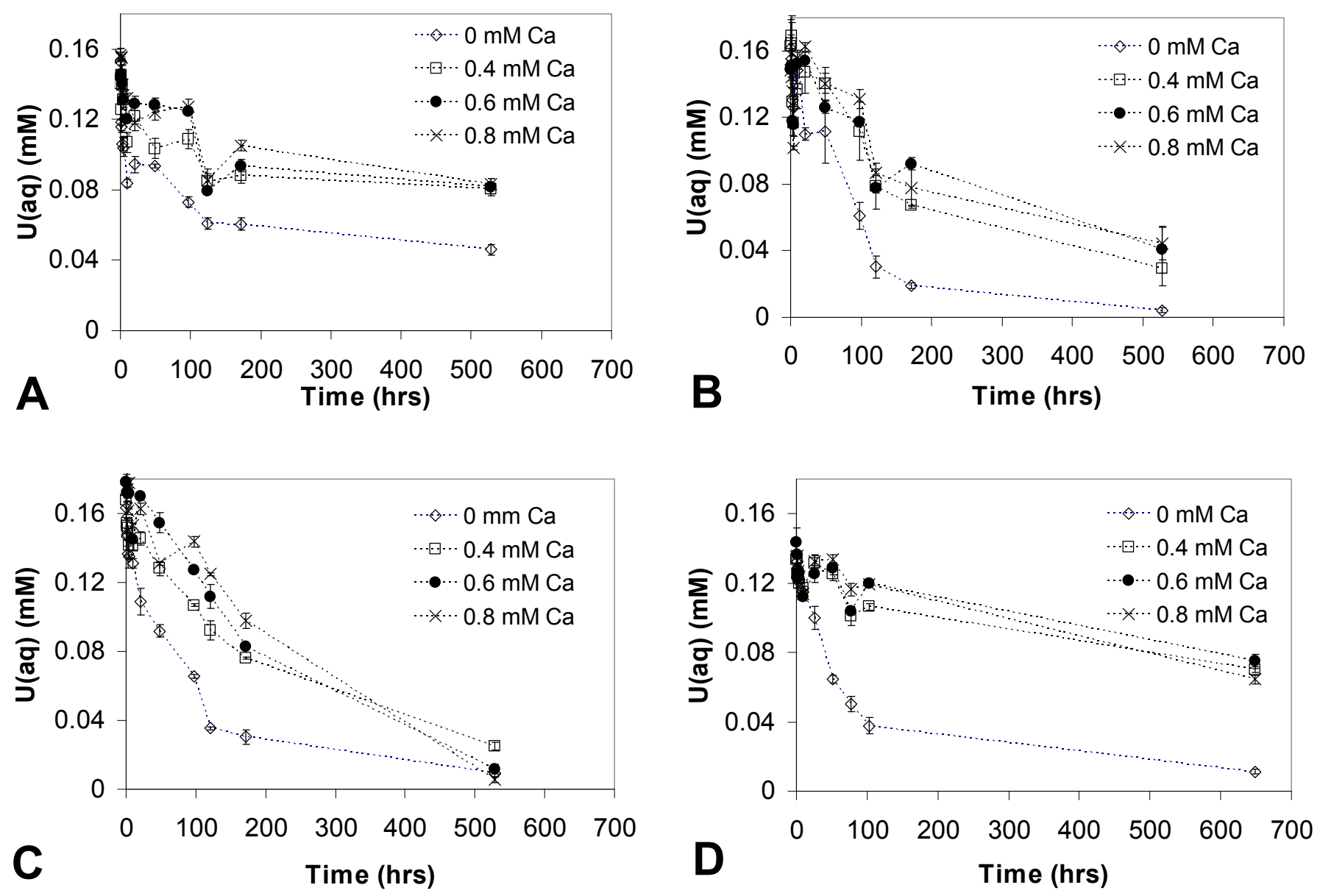

Figure 3. 


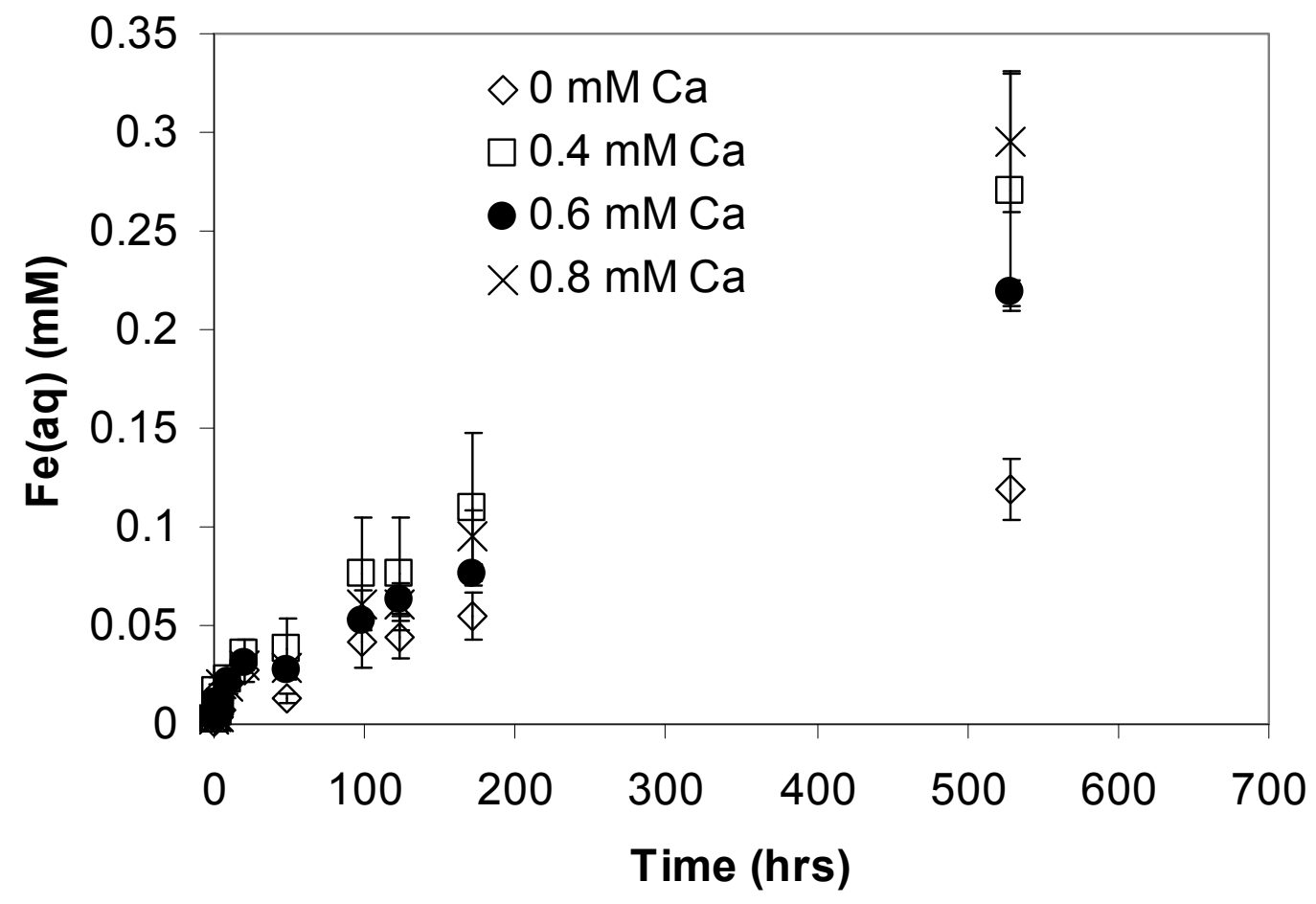

Figure 4. 


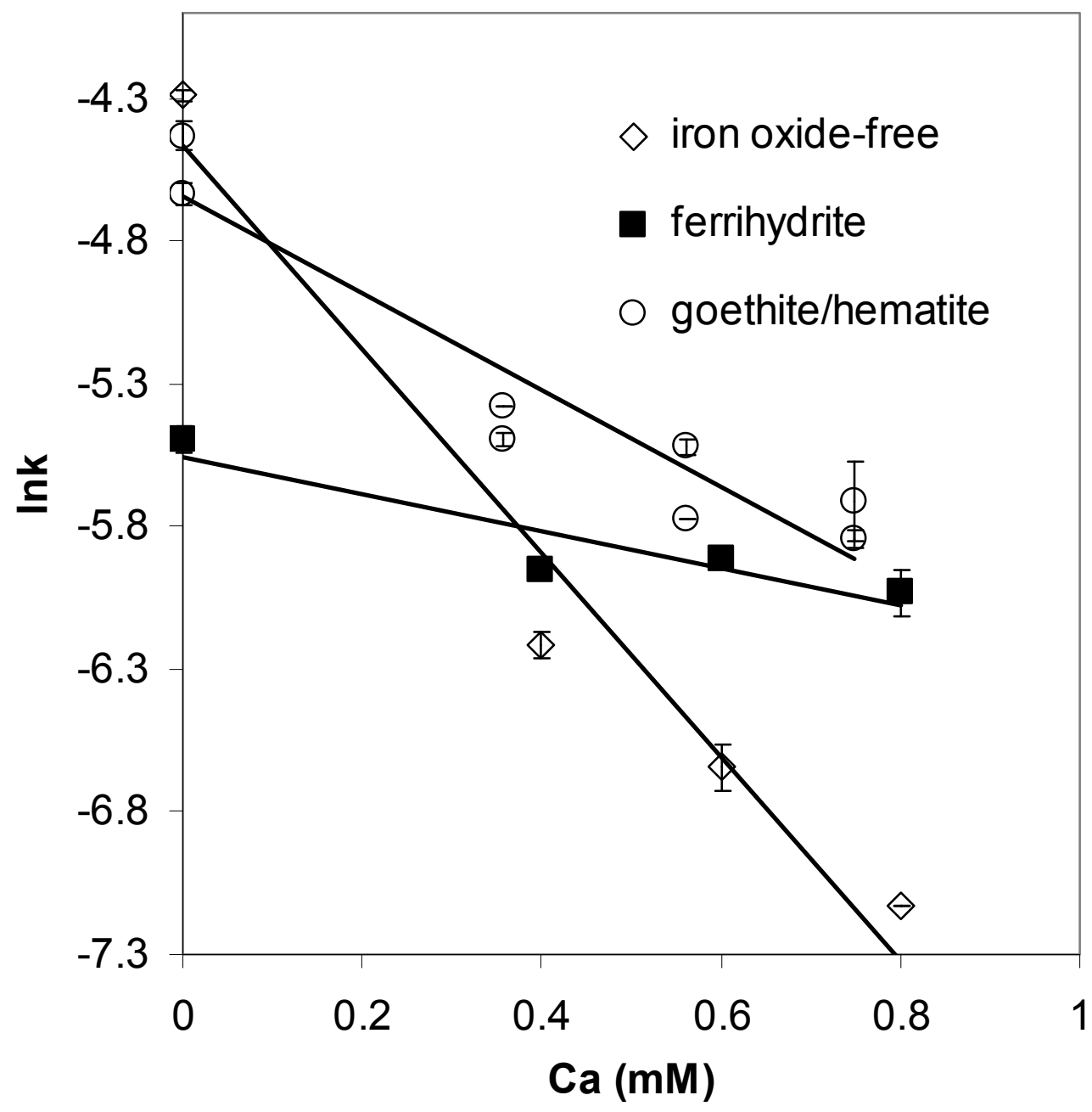

Figure 5. 

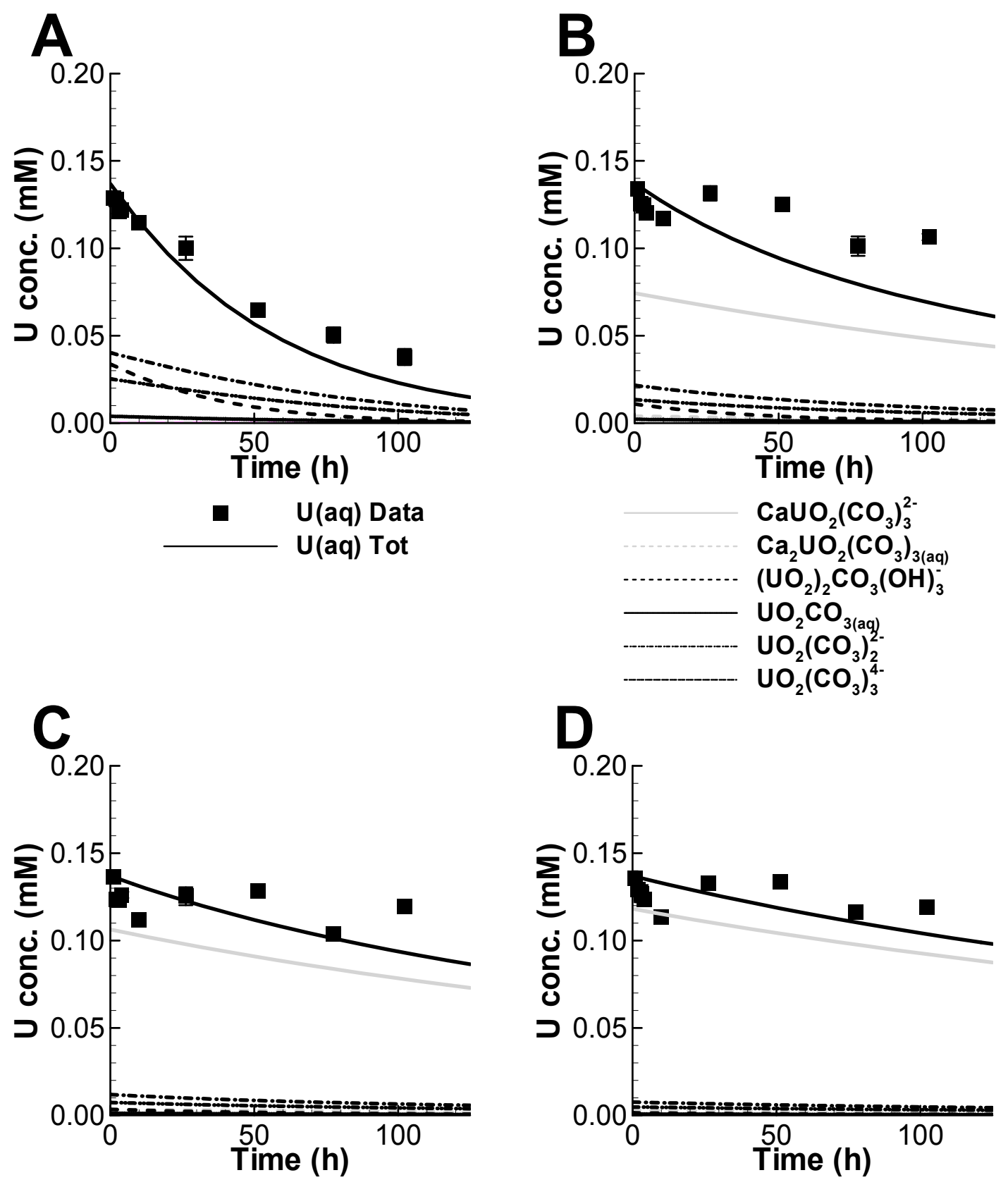

Figure 6. 

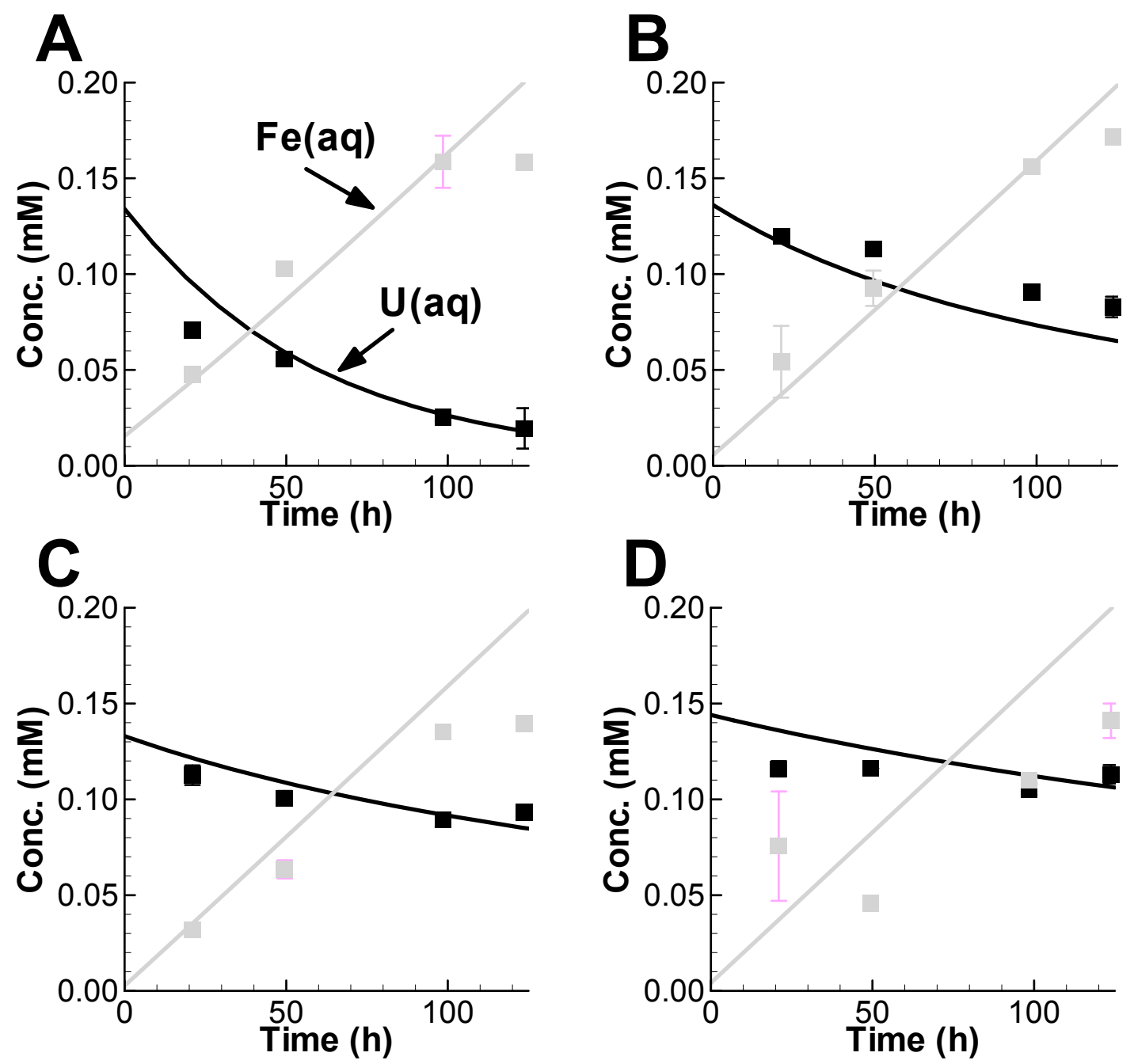

Figure 7. 